\title{
Canadian Thoracic Society 2011 guideline update: Diagnosis and treatment of sleep disordered breathing
}

\author{
John Fleetham MD¹, Najib Ayas $\mathrm{MD}^{1}$, Douglas Bradley $\mathrm{MD}^{2}$, Michael Fitzpatrick $\mathrm{MD}^{3}$, Thomas K Oliver $\mathrm{BA}^{4}$, \\ Debra Morrison $\mathrm{MD}^{5}$, Frank Ryan $M \mathrm{BB}^{1}$, Frederic Series $\mathrm{MD}^{6}$, Robert Skomro $\mathrm{MD}^{7}$, Willis Tsai $\mathrm{MD}^{8}$; \\ The Canadian Thoracic Society Sleep Disordered Breathing Committee
}

\begin{abstract}
J Fleetham, N Ayas, D Bradley, et al; The Canadian Thoracic Society Sleep Disordered Breathing Committee. Canadian Thoracic Society 2011 guideline update: Diagnosis and treatment of sleep disordered breathing. Can Respir J 2011;18(1):25-47.

The Canadian Thoracic Society (CTS) published an executive summary of guidelines for the diagnosis and treatment of sleep disordered breathing in 2006/2007. These guidelines were developed during several meetings by a group of experts with evidence grading based on committee consensus. These guidelines were well received and the majority of the recommendations remain unchanged. The CTS embarked on a more rigorous process for the 2011 guideline update, and addressed eight areas that were believed to be controversial or in which new data emerged. The CTS Sleep Disordered Breathing Committee posed specific questions for each area. The recommendations regarding maximum assessment wait times, portable monitoring, treatment of asymptomatic adult obstructive sleep apnea patients, treatment with conventional continuous positive airway pressure compared with automatic continuous positive airway pressure, and treatment of central sleep apnea syndrome in heart failure patients replace the recommendations in the 2006/2007 guidelines. The recommendations on bariatric surgery, complex sleep apnea and optimum positive airway pressure technologies are new topics, which were not covered in the 2006/2007 guidelines.
\end{abstract}

Key Words: Adult; Guidelines; Obstructive sleep apnea; Sleep disordered breathing

$\mathrm{T}$ he Canadian Thoracic Society (CTS) guidelines for the diagnosis and treatment of sleep disordered breathing were developed and published in 2006/2007 (1,2). A one-day meeting was held in Toronto, Ontario, on April 26, 2009, to initiate the process of updating specific parts of the previous guidelines. This meeting was attended by 42 Canadian physicians and dentists with an interest in sleep disordered breathing. The CTS Sleep Disordered Breathing Committee posed specific questions for each area.

\section{REFERENCES}

1. Fleetham J, Ayas N, Bradley D, et al. Canadian Thoracic Society guidelines: Diagnosis and treatment of sleep disordered breathing in adults. Can Respir J 2006;13:387-92.

2. Fleetham J, Ayas N, Bradley D, et al. Directives de la Société canadienne de thoracologie: Diagnostic et traitement des troubles respiratoires du sommeil de l'adulte. Can Respir J 2007;14:31-6.

\section{SYSTEMATIC REVIEW}

Question

What are the optimal diagnostic and treatment strategies for patients with suspected sleep disordered breathing?

\section{Mise à jour 2011 de lignes directrices de la Société canadienne de thoracologie : Diagnostic et traitement des troubles respiratoires du sommeil de l'adulte}

La Société canadienne de thoracologie (SCT) a publié un résumé des lignes directrices sur le diagnostic et le traitement des troubles respiratoires du sommeil de l'adulte en 2006-2007. Ces lignes directrices avaient été élaborées dans le cadre de plusieurs réunions tenues par un groupe d'experts, les données probantes étant classées selon le consensus du comité. Ces lignes directrices ont obtenu une belle réception, et la majorité des recommandations demeurent inchangées. La SCT a entrepris un processus plus rigoureux pour la mise à jour 2011 des lignes directrices et s'est penchée sur huit secteurs considérés comme controversés ou à l'égard desquels de nouvelles données ont émergé. Le comité de la SCT sur les troubles respiratoires du sommeil a posé des questions précises dans chaque secteur. Les recommandations au sujet des temps d'attente maximaux pour obtenir l'évaluation, de la surveillance portable, du traitement des patients adultes asymptomatiques faisant de l'apnée obstructive du sommeil, du traitement au moyen de la pression positive continue classique par rapport à la pression positive continue automatisée et du traitement de l'apnée obstructive du sommeil chez les patients atteints d'insuffisance cardiaque remplacent celles figurant dans les lignes directrices 2006-2007. Les recommandations sur la chirurgie bariatrique, l'apnée du sommeil complexe et les technologies de pression positive optimales sont de nouveaux sujets qui ne faisaient pas partie des lignes directrices 2006-2007.

\section{Objective}

The objective of the present clinical practice guideline is to inform and provide evidence-based recommendations for the diagnosis and treatment of sleep disordered breathing to physicians and health care teams involved in the clinical care of patients with sleep disordered breathing. The current guideline is needed to ensure consistency of best practice, to identify systematic gaps in care, and to provide direction for future research in the diagnosis and management of sleep disordered breathing.

\section{Introduction}

In 2006, the CTS launched a comprehensive package of guidelines covering the diagnosis and treatment of sleep disordered breathing in adults encompassing the definitions of syndrome severity, referral and diagnosis, and behavioural, pharmacological and surgical treatment. The 2006 CTS guidelines "Diagnosis and treatment of sleep disordered breathing in adults" were published in the Canadian Respiratory Journal (1). The first sleep apnea 'Slim Jim' (packet card summary of the guidelines) was developed to accompany the clinical guidelines and help drive the implementation.

${ }^{1}$ University of British Columbia, Vancouver, British Columbia; ${ }^{2}$ University of Toronto, Toronto; ${ }^{3}$ Queen's University, Kingston; ${ }^{4}$ McMaster University Hamilton, Ontario; ${ }^{5}$ Dalhousie University, Halifax, Nova Scotia; ${ }^{6}$ Laval University, Quebec City, Quebec; ${ }^{7}$ University of Saskatchewan, Saskatoon, Saskatchewan; ${ }^{8}$ University of Calgary, Calgary, Alberta

Correspondence: Dr John Fleetham, The Lung Centre, 7th Floor, Diamond Health Care Centre, 2775 Laurel Street, Vancouver, British Columbia V5Z 1M9. Telephone 604-875-4122, fax 604-875-4695, e-mail john.fleetham@vch.ca

Reprint requests: The Canadian Thoracic Society, The Lung Association - National Office, 300 - 1750 Courtwood Crescent, Ottawa, Ontario K2C 2B5. Telephone 613-569-6411 ext 270, fax 613-569-8860, e-mail ctsinfo@lung.ca 
Since 2006, the Task Force of the American Academy of Sleep Medicine has published two formal guidelines: "Clinical guidelines for the manual titration of positive airway pressure in patients with obstructive sleep apnea" (www.aasmnet.org/Resources/ ClinicalGuidelines/040210.pdf) (2), and "Clinical guidelines for the use of unattended portable monitors in the diagnosis of obstructive sleep apnea in adult patients" (3). In 2008, The National Institute for Health and Clinical Excellence (NICE) published a technology assessment titled "Continuous positive airway pressure devices for the treatment of obstructive sleep apnoea-hypopnoea syndrome: A systematic review and economic analysis" (4). These guidelines have been incorporated in the updated CTS guidelines for publication in 2011.

\section{Questions}

1. In patients with obstructive sleep apnea syndrome (OSAS), what are the current recommended maximum assessment wait times to initiate treatment that correspond to better patient outcomes?

2. What is the role of portable monitoring in the diagnosis of sleep disordered breathing?

3. Does treatment of asymptomatic adult obstructive sleep apnea (OSA) patients improve health outcomes?

4. Do OSAS patients benefit more from autotitrating positive airway pressure (APAP) than from using conventional continuous positive airway pressure (CPAP)?

5. Is bariatric surgery an effective treatment strategy in obese patients with OSAS compared with standard care, exercise and diet?

6. Does CPAP lead to improved outcomes in patients with heart failure and central sleep apnea syndrome (CSAS) compared with the standard medical therapy for heart failure (HF)?

7. Is complex sleep apnea (CompSA) a distinct clinical syndrome and, if so, what criteria should be used to make the diagnosis of CompSA?

8. What are the optimum positive airway pressure technologies available to patients with OSAS?

\section{Target population}

The present clinical practice guideline applies to adults with sleep disordered breathing.

\section{Target users}

The present clinical practice guideline is intended for use by health care teams who care for patients with sleep disordered breathing. Specifically, family physicians and specialist physicians (eg, respirologists, internists, otolaryngologists, anesthetists, neurologists and psychiatrists), and other health care professionals (nurses, respiratory therapists and polysomnographic technologists) who work in health care teams that currently care for patients with sleep disordered breathing can use these guidelines to help inform their clinical practice. The guideline is also intended for use by patient groups to support advocacy on behalf of access to optimal health care for patients with sleep disordered breathing, and health care institutions in planning and delivering optimal care for patients with sleep disordered breathing.

\footnotetext{
Methodology

Guideline development: The current clinical practice guideline was developed according to the convention of the Appraisal of Guidelines for Research and Evaluation (AGREE) II instrument - the current gold standard in appraising the reporting of clinical practice guidelines (The AGREE Research Trust, May, 2009). The CTS Sleep Disordered Breathing Committee, comprising respirologists with clinical content experience in each of the topic areas, a research coordinator and a methodologist, represents the expertise needed to reliably provide guidance on the diagnosis and treatment of individuals with sleep apnea. The CTS Sleep Disordered Breathing Committee conducted a systematic review of the literature current to February 2009. Before completion, the guideline was distributed to content experts across Canada for the opportunity to provide feedback concerning
}

the collection and interpretation of the evidence, as well as the development of the recommendations that account for the strengths and weaknesses of the evidence, and the judgements derived through expert consensus opinion. Final consensus on the recommendations was reached through a formal voting process that was anonymized. The CTS Sleep Disordered Breathing Committee has committed to periodically review the literature on at least a biannual basis. The sleep disordered breathing guideline will be updated as new or compelling evidence is identified.

Literature search strategy: The literature was searched using MEDLINE (OVID: 1996 through February 2009), EMBASE OVID: (1996 through October 2009), the Cochrane Library (OVID; Issue 3, 2008), the Canadian Medical Association InfoBase, and the National Guideline Clearinghouse. The reference lists of related papers and recent review articles were also scanned for additional citations.

The literature search of the electronic databases combined the following MeSH heading terms and text search terms to identify the body of published evidence on sleep apnea related to the following: lung diseases, central sleep apnea, pulmonary disease, sleep disordered breathing, Cheyne-Stokes respiration, adaptive servoventilation, CPAP, heart failure, obstructive sleep apnea, diagnosis of OSA, wait times, public health and OSA, morbid obesity and OSA, weight loss and sleep apnea, obesity management and sleep apnea, health outcomes and bariatric surgery, auto CPAP, mandibular advancement device, mandibular advancement splint, oral appliance, mandibular repositioning appliance, mandibular advancement appliance, tongue retaining device, tongue advancing device, obstructive sleep apnea syndromes and mortality, morbidity, exercise capacity, left ventricular ejection fraction, sympathetic nervous system activity, MVAs, HrQoL, sleep apnea severity, efficacy in terms of nocturnal parameters - snoring, AHI, sleep structure, oxygenation, and daytime symptoms - sleepiness, mood, blood pressure, diabetes, sleep fragmentation, snoring, apnea + hypopnea index, central sleep apnea, oxygen saturation, CPAP compliance, CPAP choice AND Limits: Humans, English/ or French/, All Adult: 19+ years

Study selection criteria: Articles were selected for inclusion in the systematic review of the evidence if they reported data on factors that influence the risk of developing or being diagnosed with sleep apnea, or those that inform the optimum treatment for individuals with sleep apnea.

In descending order of preference, the minimum levels of evidence required to inform the clinical questions were as follows: evidencebased clinical practice guidelines, systematic reviews, meta-analyses, randomized controlled trials (RCTs), nonrandomized comparative studies, prospective or retrospective single-cohort case series, and case reports.

Articles were excluded from the systematic review of the evidence if they were reported in a language other than English or involved uniquely pediatric populations.

Outcomes of interest: Studies were required to report data on at least one of the following outcomes of interest: mortality, morbidity, exercise capacity, left ventricular ejection fraction (LVEF), sympathetic nervous system activity, motor vehicle collisions, health-related quality of life (HrQoL), sleep apnea severity (according to the apnea/ hypopnea index $[\mathrm{AHI}]$ ), efficacy in terms of nocturnal parameters snoring, AHI, sleep structure, oxygenation, and daytime symptoms (eg, sleepiness, mood), blood pressure, diabetes, sleep fragmentation, snoring, AHI, central sleep apnea (CSAS), oxygen saturation, CPAP compliance or CPAP choice.

\section{Results}

Literature search: Table 1 summarizes the overall literature search results comprising the evidence base to inform the optimum detection and treatment of sleep apnea. Results of the literature search are reported in each of the separate subsections related to the questions of interest. Key recommendations and the supporting level of evidence were developed around each section and, where possible, barriers to implementation of the recommendations were identified. 
TABLE 1

Literature search results informing home mechanical ventilation in a variety of patient populations

\begin{tabular}{ll}
\hline Section & Topic \\
\hline I & Maximum assessment wait times \\
III & Portable monitoring \\
IV & Treatment of asymptomatic patients with obstructive sleep apnea \\
V & Treatment with conventional CPAP compared with automatic CPAP \\
VI & Treatiatric surgery \\
VII & Complex sleep apnea \\
VIII & Optimum positive airway pressure technologies \\
\hline
\end{tabular}

CPAP Continuous positive airway pressure

\section{REFERENCES}

1. Fleetham J, Ayas N, Bradley D, et al. Canadian Thoracic Society guidelines: Diagnosis and treatment of sleep disordered breathing in adults. Can Respir J 2006;13:387-92.

2. Kushida CA, Chediak A, Berry RB, et al. Clinical guidelines for the manual titration of positive airway pressure in patients with obstructive sleep apnea. J Clin Sleep Med 2008;4:157-71.

3. Collop NA, Anderson WM, Boehlecke B, et al. Clinical guidelines for the use of unattended portable monitors in the diagnosis of obstructive sleep apnea in adult patients. J Clin Sleep Med 2007;3:737-47.

4. Guest JF, Helter MT, Morga A, Stradling JR. Continuous positive airway pressure devices for the treatment of obstructive sleep apnoea-hypopnoea syndrome: A systematic review and economic analysis. Thorax 2008;63:860-5.

\section{SECTION I: MAXIMUM ASSESSMENT WAIT TIMES}

\section{Question}

In patients with OSAS, what are the current recommended maximum assessment wait times to initiate treatment that correspond to better patient outcomes?

\section{Introduction}

While it is recognized that OSAS prevalence rates are rising and resulting in increasing numbers of referrals for sleep assessments and delays in accessing sleep services, there are currently very few evidencebased recommendations that address the issue of wait times for sleep diagnostic services. Furthermore, there have been few published surveys pertaining to access to sleep diagnostic services. Before publication of the CTS guidelines in 2006, Flemons et al (1) surveyed five countries and reported variable wait times ranging from a few months in the United States and Belgium, to a few years in Canada and the United Kingdom (UK). They also reported a wide disparity in access to polysomnography (PSG) in Canada. The CTS guidelines published in 2006 recommended that assessments be completed in four weeks for priority 1 (urgent) cases, within two months for priority 2 cases and within six months for all suspected cases. Priority was assigned to patients with significant daytime sleepiness in safety-critical occupations, and those with comorbidities or an oxygen desaturation index (ODI) of greater than 30 (2).

A recent study of access to sleep apnea services in Ontario (3) revealed a mean time of 11.6 months to initiate CPAP therapy and 16.2 months to initiate surgical therapy. Sleep laboratory availability appeared to be a factor affecting access to therapy, with each additional sleep laboratory in a community associated with a $20 \%$ decrease in overall wait time.

In Canada, access to level 1 in-laboratory PSG or level III portable monitoring varies greatly. While there has been expansion of these services in many provinces, there are still areas of Canada with no sleep diagnostic services. In areas with adequate access to diagnostic services, access to CPAP therapy is often limited. There are no published data regarding the availability of level III sleep monitoring or oral appliances in Canada.

Access to sleep diagnostic services and therapy is often poorly defined, and measurement of wait times can be imprecise. It is generally assumed that the wait for OSAS testing begins with a referral to a sleep medicine consultant or a sleep diagnostic facility. There are, however, often delays in recognizing OSAS at the primary care level.
TABLE I-1

Literature search results

\begin{tabular}{|c|c|c|c|c|c|c|}
\hline \multirow[b]{2}{*}{$\begin{array}{l}\text { Author } \\
\text { (reference), } \\
\text { year }\end{array}$} & \multirow[b]{2}{*}{$\begin{array}{l}\text { Study } \\
\text { type }\end{array}$} & \multirow[b]{2}{*}{$\begin{array}{c}\text { Patients, } \\
n\end{array}$} & \multicolumn{4}{|c|}{ Outcomes } \\
\hline & & & Sleepiness & QoL & Cognitive & $\begin{array}{c}\text { Health } \\
\text { care } \\
\text { costs }\end{array}$ \\
\hline $\begin{array}{r}\text { Pelletier-Fleury } \\
\text { et al (4), } 2004\end{array}$ & RCT & 171 & Yes & Yes & Yes & Yes \\
\hline SIGN (5), 2003 & $\begin{array}{l}\text { Clinical } \\
\text { practice } \\
\text { guideline }\end{array}$ & $N / A$ & - & - & - & - \\
\hline $\begin{array}{l}\text { Dept of Health, } \\
\text { NHS, UK (6), } \\
2009\end{array}$ & Guideline & N/A & - & - & - & - \\
\hline $\begin{array}{l}\text { IMPRESS (7), } \\
2009 \text { (BTS, ARTP, } \\
\text { GPAG, SATA) }\end{array}$ & Guideline & $N / A$ & $\begin{array}{l}- \\
-\end{array}$ & $\begin{array}{l}- \\
-\end{array}$ & - & $\begin{array}{l}- \\
-\end{array}$ \\
\hline
\end{tabular}

ARTP The Association for Respiratory Technology and Physiology; BTS British Thoracic Society; Dept Department; GPAG General Practioner's Asthma Group; IMPRESS Improving and Integrating Respiratory Services in the National Health Service (NHS); N/A Not available; QoL Quality of life; RCT Randomized controlled trial; SATA Sleep Apnea Trust; SIGN Scottish Intercollegiate Guidelines Network; UK United Kingdom

There is a paucity of evidence that addresses the question of appropriate wait times for the diagnosis and management of OSAS.

\section{Results}

Literature search: The search was performed using search criteria mentioned in the introduction, but was extended to include the websites of the American Academy of Sleep Medicine, American College of Chest Physicians, American Thoracic Society, British Thoracic Society (BTS), the Australian Sleep Society and relevant links. The search yielded 405 citations, of which four - one RCT and three guidelines - formed the basis of the present review.

Study characteristics and outcomes: Pelletier-Fleury et al (4) published the results of an RCT performed at two teaching hospitals in France. A total of 171 patients were randomly assigned to either immediate PSG and CPAP titration, or to PSG within six months. Patients with severe OSAS (AHI of greater than 30) whose PSG was deferred were deprived of a significant improvement in daytime sleepiness and quality of life. Over the six-month follow-up period, the delay in treatment did not appear to affect attention and concentration as measured by trail-making tests or health care costs; however, the incremental cost-effectiveness ratio related to prompt introduction of treatment was lower in patients with severe OSAS. Individuals with mild to moderate OSAS (AHI of greater than 5 and lower than 30) in the treatment arm experienced significant improvement in daytime sleepiness.

Previously published CTS guidelines suggest that patients with suspected OSAS be triaged based on the severity of subjective daytime sleepiness, occupation, ODI and comorbidities. These guidelines recommended that individuals with the highest priority be investigated within two to four weeks, and those deemed less urgent to be assessed within six months. Since the most recent publication of the CTS sleep disordered breathing guidelines, two guideline documents from the UK (Scottish Intercollegiate Guidelines Network [SIGN] and Improving and Integrating Respiratory Services in the National Health Service [IMPRESS]) addressed the question of wait times (5-7) (Table I-1). In the SIGN document, it was recommended that patients with OSAS experiencing excessive daytime sleepiness while operating vehicles or those with respiratory failure be considered for urgent referral to a sleep centre (grade of recommendation C). However, there was no specific information regarding acceptable wait times. The IMPRESS document refers to the UK Department of Health 2008 sleep disorders pathway, which recommended completion of assessment and treatment in 18 weeks, but provided no information on patient triage or grades of recommendation. Information provided on the UK 
Department of Health website suggests that, despite an increase in OSAS recognition and prevalence rates, there was considerable improvement in wait times for sleep disordered breathing testing between October 2006 and October 2008.

\section{Discussion}

The benefits of OSAS treatment are well known and are summarized elsewhere in the current document. CPAP and oral appliances have been demonstrated to improve somnolence, QoL, AHI and nocturnal oxygen desaturation. There is also evidence that untreated OSAS poses a significant financial burden on the health care system and that OSAS therapy decreases health care costs.

An improvement in some of these outcomes (eg, AHI) with therapy is immediate, while in others it may take weeks, months (daytime sleepiness and QoL) or years (motor vehicle collisions and health care costs).

Despite the proven benefits of OSAS therapy, many Canadians are experiencing unacceptably long wait times for diagnosis and management. Although recent federal and provincial efforts have focused on addressing wait times for diagnostic services across Canada, OSAS is not listed in the wait list documents of the Canadian Institute for Health Information, or those of Ontario or Saskatchewan.

There is little evidence-based data to determine the maximum wait times for assessment of sleep disordered breathing. Previously published CTS guidelines suggested that patients with suspected OSAS be triaged based on the severity of subjective daytime sleepiness, occupation, ODI and comorbidities. Based on expert opinion, these guidelines recommended that individuals with the highest priority be investigated within two weeks, and those deemed to be less urgent to be assessed within six months. A somewhat different approach has been adopted by the SIGN guidelines and supported by the BTS, which recommend urgent referral to a sleep centre only if there is coexisting chronic obstructive pulmonary disease (COPD), respiratory failure, or occupational or driving hazard (grade of recommendation C). These guidelines, however, do not define the urgency of assessment.

Publication of the NICE CPAP guideline has led to the development of a service specification document and OSA care map in the UK (8). These guidelines (IMPRESS) - jointly developed by the BTS and Sleep Apnea Trust - recommend that assessment and therapy of OSAS be completed within 18 weeks. The document is based on consensus opinion and provides no scientific evidence to support the recommendations.

\section{Summary}

The existing evidence to address the question of maximum wait times for OSAS assessment and management is very limited, and is based on one RCT from France and expert opinion from Canada and the UK. These documents recommend completion of all assessments within 18 to 24 weeks, and urgent cases within four weeks.

\section{Question \#1}

In patients with OSAS, what are the current recommended maximum assessment wait times to initiate treatment that correspond to better patient outcomes?

\section{Recommendations}

The following recommendation is based on limited evidence from one RCT, three guidelines and the consensus of the sleep apnea expert panel:

1) Patients with suspected severe OSAS, and patients working in safety-critical occupations should be investigated within four weeks of the referral to a diagnostic sleep facility. (Grade of recommendation: $1 \mathrm{C}$ )

2) Patients with the following comorbidities or conditions should be investigated within four weeks: unstable ischemic heart disease, recent cerebrovascular disease, congestive heart failure, refractory systemic hypertension, obstructive/restrictive lung disease, pulmonary hypertension, hypercapnic respiratory failure or pregnancy. All patients within six months of the referral to the diagnostic sleep facility. (Grade of recommendation: 2C)

\section{REFERENCES}

1. Flemons WW, Douglas NJ, Kuna ST, Rodenstein DO, Wheatley J. Access to diagnosis and treatment of patients with suspected sleep apnea. Am J Respir Crit Care Med 2004;169:668-72.

2. Fleetham J, Ayas N, Bradley D, et al; the CTS Sleep Disordered Breathing Committee. Canadian Thoracic Society guidelines: Diagnosis and treatment of sleep disordered breathing in adults. Can Respir J 2006;13:387-92.

3. Rotenberg B, George C, Sullivan K, Wong E. Wait times for sleep apnea care in Ontario: A multidisciplinary assessment. Can Respir J 2010;17:170-4.

4. Pelletier-Fleury N, Meslier N, Gagnadoux F, et al. Economic arguments for the immediate management of moderate-to-severe obstructive sleep apnoea syndrome. Eur Respir J 2004;23:53-60.

5. Scottish Intercollegiate Guideline Network (SIGN). 73: Management of obstructive sleep apnoea/hypopnoea syndrome in adults; A national clinical guideline. Edinburgh: S16N, 2003.

6. Department of Health, UK. Transforming Respiratory and Sleep Diagnostic Services; a good practise guide. 2009.

7. IMPRESS Guidelines 2009. <http://www.impressresp.com/Portals/0/ IMPRESS/OSAS4-web.pdf> (Accessed November 2010).

8. National Institute for Health and Clinical Excellence (NICE). Continuous positive airway pressure for the treatment of obstructive sleep apnoea/hypopnoea syndrome. London: NICE, 2008.

\section{Question}

\section{SECTION II: PORTABLE MONITORING}

What is the role of portable monitoring in the diagnosis of sleep disordered breathing?

\section{Introduction}

Current evidence indicates that access to sleep diagnostic services is limited in many provinces and territories. Given that effective treatment for OSAS exists, the current wait times for OSAS diagnosis and therapy in Canada are not acceptable. This ongoing disparity between the demand for services and the availability of PSG has prompted research into simpler diagnostic and management strategies for OSAS, including portable monitoring.

\section{Results}

Literature search: Five articles comprising two recent systematic reviews and three recent RCTs formed the evidence base for the systematic review of evidence regarding the role of portable monitoring in the diagnosis and management of OSAS. A systematic review was commissioned by the Centers for Medicare and Medicaid Services (CMS) to address its coverage policy for sleep testing for the diagnosis of OSAS. Another systematic review updated a previous review conducted by the American Academy of Sleep Medicine. While not meeting the specific selection criteria for either of the aforementioned systematic reviews, one RCT (1) was included in their evidence base because it contained important outcome data. Two other RCTs, one of which was a multicentre randomized noninferiority trial, were too recent for inclusion in the aforementioned systematic reviews (Table II-1).

\section{Outcomes}

Agreement of individual measures of AHI: Difference versus average analysis (Bland-Altman plots) from a high-quality systematic review (2) indicate that the AHI or respiratory disturbance index measurements from portable monitors and facility-based PSG are not interchangeable. Progressively increasing differences are apparent between type II, III and IV portable monitors, and facility-based PSG, particularly at the higher end of the AHI spectrum, and especially when measurements were not performed simultaneously. This is true for both manual and automatic scoring.

Diagnosis of OSAS: Based on a high-quality systematic review (2), there are limited data to indicate that type II, III and IV portable monitors are able to predict AHI suggestive of OSAS with high positive likelihood ratios and low negative likelihood ratios. The performance of portable monitors was worse in studies conducted in the home setting 
TABLE II-1

Literature search results

\begin{tabular}{|c|c|c|c|c|c|c|c|c|c|}
\hline \multirow{2}{*}{$\begin{array}{l}\text { Author } \\
\text { (ref), year }\end{array}$} & \multirow{2}{*}{$\begin{array}{l}\text { Study type; } \\
\text { quality grade }\end{array}$} & \multirow{2}{*}{$\begin{array}{c}\text { Patients, } \\
\mathbf{n} \\
\end{array}$} & \multirow[b]{2}{*}{ Intervention } & \multirow{2}{*}{$\begin{array}{c}\text { Follow-up } \\
\text { weeks }\end{array}$} & \multicolumn{5}{|c|}{ Outcome } \\
\hline & & & & & 1 & 2 & 3 & 4 & 5 \\
\hline $\begin{array}{l}\text { Mulgrew } \\
\text { et al (1), } \\
2007\end{array}$ & $\begin{array}{l}\text { Single-centre, } \\
\text { randomized } \\
\text { controlled } \\
\text { trial; } \\
\text { A }\end{array}$ & 68 & $\begin{array}{l}\text { PSG versus } \\
\text { clinical } \\
\text { prediction rule } \\
\text { + portable } \\
\text { monitor } \\
\text { (oximetry) + } \\
\text { APAP }\end{array}$ & 12 & $\begin{array}{l}\text { Residual sleep } \\
\text { apnea on CPAP } \\
\text { (PSG-AHI) } \\
\Delta 0.8 \text { (-0.9 to } \\
2.3) / \mathrm{h}(\mathrm{NS})\end{array}$ & $\begin{array}{l}\text { Subjective } \\
\text { sleepiness } \\
\text { (ESS) } \\
\Delta 0.0(-2.0 \text { to } 2.0) \\
\text { (NS) }\end{array}$ & $\begin{array}{l}\text { Quality of life } \\
\text { (SAQLI) } \\
\Delta-0.19 \\
\text { (-0.7 to 0.3) } \\
\text { (NS) }\end{array}$ & $\begin{array}{l}\text { CPAP } \\
\text { adherence } \\
\Delta-1.12 \\
(-2.0 \text { to }-0.2) \\
\text { h/night } \\
(P=0.021)\end{array}$ & $\begin{array}{l}\text { CPAP pressure } \\
\begin{array}{l}\Delta-0.9 \\
(-2.0 \text { to } 0.1) \\
\mathrm{cmH}_{2} \mathrm{O} \\
(\mathrm{NS})\end{array}\end{array}$ \\
\hline $\begin{array}{c}\text { Trikalinos } \\
\text { et al (2) } \\
2007\end{array}$ & $\begin{array}{l}\text { Systematic } \\
\text { review; } \\
\text { B }\end{array}$ & $\begin{array}{c}95 \text { studies } \\
+ \text { Mulgrew } \\
\text { et al (1) }\end{array}$ & $\begin{array}{l}\text { PSG versus } \\
\text { type I, II, III or } \\
\text { IV portable } \\
\text { monitors }\end{array}$ & - & $\begin{array}{l}\text { Response to } \\
\text { CPAP and } \\
\text { changes in } \\
\text { clinical } \\
\text { outcomes }\end{array}$ & $\begin{array}{l}\text { Agreement of } \\
\text { individual } \\
\text { measurements of } \\
\text { AHI }\end{array}$ & $\begin{array}{l}\text { Diagnosis of } \\
\text { OSAS }\end{array}$ & $\begin{array}{l}\text { Markov model } \\
\text { - proportion } \\
\text { offered } \\
\text { CPAP, time } \\
\text { to diagnosis } \\
\text { and } \\
\text { treatment }\end{array}$ & $\begin{array}{l}\text { Other: } \\
\text { automated } \\
\text { versus manual } \\
\text { scoring; errors; } \\
\text { complications; } \\
\text { data loss; and } \\
\text { corruption }\end{array}$ \\
\hline $\begin{array}{l}\text { Collop } \\
\text { et al (5), } \\
2007\end{array}$ & $\begin{array}{l}\text { Systematic } \\
\text { review; } \\
\text { B }\end{array}$ & $\begin{array}{c}36 \text { studies } \\
+ \text { Mulgrew } \\
\text { et al }(1)\end{array}$ & $\begin{array}{l}\text { PSG versus } \\
\text { type III } \\
\text { portable } \\
\text { monitors }\end{array}$ & - & $\begin{array}{l}\text { Indications for } \\
\text { portable } \\
\text { monitoring }\end{array}$ & $\begin{array}{l}\text { Minimum technical } \\
\text { requirements }\end{array}$ & $\begin{array}{l}\text { Clinical setting } \\
\text { and } \\
\text { methodological } \\
\text { considerations }\end{array}$ & - & - \\
\hline $\begin{array}{l}\text { Berry } \\
\text { et al (3), } \\
2008\end{array}$ & $\begin{array}{l}\text { Single-centre, } \\
\text { randomized } \\
\text { controlled } \\
\text { trial; } \\
\text { B }\end{array}$ & 106 & $\begin{array}{l}\text { PSG versus } \\
\text { clinical } \\
\text { prediction rule } \\
\text { + portable } \\
\text { monitor (type } \\
\text { IV) + } \\
\text { APAP }\end{array}$ & 6 & $\begin{array}{l}\text { CPAP adherence } \\
5.2 \text { versus } \\
5.25 \text { h/night } \\
\text { (NS) }\end{array}$ & $\begin{array}{l}\text { Subjective } \\
\text { sleepiness } \\
\text { (ESS) } \\
\text { change }-6.5 \\
\text { versus }-6.97 \\
\text { (NS) }\end{array}$ & $\begin{array}{l}\text { Quality of life } \\
\text { (FOSQ) } \\
\text { change } 3.1 \\
\text { versus } 3.3 \\
\text { (NS) }\end{array}$ & $\begin{array}{l}\text { Patient } \\
\text { satisfaction } \\
\text { score } \\
12.8 \text { versus } \\
12.2 \\
\text { (NS) }\end{array}$ & $\begin{array}{l}\text { Residual sleep } \\
\text { apnea on CPAP } \\
\text { (CPAP } \\
\text { machine }- \text { AHI) } \\
\text { 3.5/h versus } \\
5.3 / h \\
\text { (NS) }\end{array}$ \\
\hline $\begin{array}{l}\text { Antic } \\
\text { et al (4), } \\
2009\end{array}$ & $\begin{array}{l}\text { Multicentre } \\
\text { randomized } \\
\text { controlled } \\
\text { noninferiority } \\
\text { trial; } \\
\text { A }\end{array}$ & 195 & $\begin{array}{l}\text { PSG versus } \\
\text { nurse-led } \\
\text { care - clinical } \\
\text { prediction rule } \\
+ \text { portable } \\
\text { monitor } \\
\text { (oximetry) + } \\
\text { APAP }\end{array}$ & 12 & $\begin{array}{l}\text { Subjective } \\
\text { sleepiness } \\
\text { (ESS) } \\
\Delta-0.13(-1.52 \\
\text { to 1.25) (NS); } \\
\text { objective } \\
\text { sleepiness } \\
\text { (MWT) } \\
\Delta-1.49(-4.76 \\
\text { to 1.78) min } \\
\text { (NS) }\end{array}$ & $\begin{array}{l}\text { Quality of life } \\
\text { (SF-36); } \\
\text { vitality } \\
\Delta-0.81(-6.75 \text { to } \\
5.12) \text { (NS); } \\
\text { mental health } \\
\Delta 0.27(-4.71 \text { to } \\
5.27)(\mathrm{NS}) ; \\
\text { (FOSQ) } \\
\Delta-0.38(-5.97 \text { to } \\
5.20)(\mathrm{NS})\end{array}$ & $\begin{array}{l}\text { Neurocognitive } \\
\text { function - } \\
\text { executive maze } \\
\text { change } \\
\Delta-0.92(-2.57 \\
\text { to } 0.73) \mathrm{NS} ; \\
\text { errors made } \\
\Delta-0.71 \\
(-15.68 \text { to } \\
14.27) \mathrm{NS}\end{array}$ & $\begin{array}{l}\text { CPAP } \\
\text { adherence } \\
\Delta-0.45 \\
(-1.26 \text { to } \\
0.36) \mathrm{h} \\
(\mathrm{NS})\end{array}$ & $\begin{array}{l}\text { Other: } \\
\text { patient } \\
\text { satisfaction } \\
\text { (NS); } \\
\text { cost } \\
\Delta-\$ 1,111 \\
(\$ 1,084 \text { to } \\
\$ 1,137) \\
\text { Australian } \\
\text { dollars }\end{array}$ \\
\hline
\end{tabular}

$\triangle$ difference (95\% CI); AHI Apnea/hypopnea index; APAP Automatic continuous positive airway pressure; CPAP Continuous positive airway pressure; ESS Epworth Sleepiness Scale; FOSQ Functional Outcomes of Sleep Questionnaire; PSG Polysomnography; MWT Maintenance of wakefulness test; NS Not statistically significant; OSAS Obstructive sleep apnea syndrome; PSG Polysomnography; ref Reference; SAQLI Sleep Apnea Quality of Life Index; SF-36 Short Form Health Survey

compared with studies performed in a specialized sleep laboratory, with between-night variability being a plausible explanation.

Residual sleep apnea: Based on limited data from two RCTs $(1,3)$, there is no difference in the degree of residual sleep apnea on CPAP between patients managed using PSG versus ambulatory strategies using portable monitoring and APAP.

Sleepiness and QoL: Limited data from three RCTs $(1,3,4)$ indicated no differences in subjective or objective measures of sleepiness, or general or disease-specific QoL between patients managed using PSG versus those managed using ambulatory strategies with portable monitoring and APAP.

CPAP adherence: Based on a high-quality systematic review (2), baseline AHI from facility-based PSG is only modestly associated with response to CPAP among persons with a high probability for severe OSAS. Thus, differences in baseline AHI cannot be used to accurately predict CPAP use or response to CPAP. Limited data from three RCTs $(1,3,4)$ indicate that there is no difference in CPAP adherence between patients managed using PSG versus those managed using an ambulatory strategy with portable monitoring and APAP.

CPAP pressure: Limited data from three RCTs $(1,3,4)$ indicated no difference in final CPAP pressure between patients managed using PSG versus an ambulatory strategy using APAP.
Patient satisfaction: Limited data from three RCTs $(1,3,4)$ suggested equivalent or greater satisfaction with ambulatory versus PSG-based management.

Neurocognitive function: Limited data from one high-quality RCT (4) indicated no differences in executive neurocognitive function between patients managed using PSG versus an ambulatory strategy.

\section{Discussion}

Based largely on the results of the systematic review (2) that the CMS had commissioned, the CMS recently found that the evidence was sufficient to determine the following: that the results of type II, III and IV (excluding devices with fewer than three channels) portable monitors can be used by a treating physician to diagnose OSAS; that the use of such sleep testing technologies demonstrates improved health outcomes in Medicare beneficiaries who have OSAS and receive the appropriate treatment; and that these tests are, therefore, reasonable and necessary. Additionally, results from two high-quality RCTs $(1,4)$ indicated that oximetry had similar utility when used within the appropriate clinical context. The most recent American Academy of Sleep Medicine clinical guidelines on portable monitoring for the diagnosis of OSAS (5), which were cognizant of the results of the CMS systematic review (but did not reference them), recommend that 
portable monitoring be performed only in conjunction with a complete sleep evaluation supervised by qualified sleep medicine practitioners in patients with a high pretest probability of OSAS, and as part of a comprehensive patient care model.

\section{Question \#2}

What is the role of portable monitoring in the diagnosis of sleep disordered breathing?

\section{Recommendations}

The following recommendations are based on the evidence from five studies, two systematic reviews, three randomized controlled trials and the consensus of the sleep apnea expert panel.

1. Level I (complete laboratory technologist-attended PSG remains the accepted standard for evaluation of sleep disordered breathing and is the test of choice when readily available. (Grade of recommendation: $1 \mathrm{~B}$ )

2. Level II, III and IV (including oximetry) portable monitoring studies can be used to confirm the diagnosis of OSAS and institute appropriate treatment in patients with a moderate to high pretest probability of this disorder when integrated into a package of care that includes the appropriate level of physician and allied health professional expertise, and the back-up availability of PSG (Grade of recommendation: 1B)

3. These devices should be used only with caution in patients with comorbid diseases and for the diagnosis of other forms of sleep disordered breathing. (Grade of recommendation: 2C)

4. The limitations of overnight oximetry in distinguishing between the different types of sleep disordered breathing must be fully appreciated before they are used to make diagnostic and therapeutic decisions. (Grade of recommendation: 1B)

\section{REFERENCES}

1. Mulgrew AT, Fox N, Ayas NT, Ryan CF. Diagnosis and initial management of obstructive sleep apnea without polysomnography: A randomized validation study. Ann Intern Med 2007;146:157-66.

2. Trikalinos TA, Ip S, Raman G, et al. Technology assessment: Home diagnosis of obstructive sleep apnea hypopnea syndrome. Bethesda: Agency for Healthcare Research and Quality, Department of Health and Human Services, 2007.

3. Berry RB, Hill G, Thompson L, McLaurin V. Portable monitoring and autotitration versus polysomnography for the diagnosis and treatment of sleep apnea. Sleep 2008;31:1423-31.

4. Antic NA, Buchan C, Esterman A, et al. A randomized controlled trial of nurse-led care for symptomatic moderate-severe obstructive sleep apnea. Am J Respir Crit Care Med 2009;179:501-8.

5. Collop NA, Anderson WM, Boehlecke B, et al. Clinical guidelines for the use of unattended portable monitors in the diagnosis of obstructive sleep apnea in adult patients. J Clin Sleep Med 2007;3:737-47.

6. Phurrough S, Jacques L, Stiller J, Brechner R. Coverage decision memorandum for sleep testing for obstructive sleep apnea (OSA) (CAG-00405N). Baltimore: Centers for Medicare and Medicaid, 2009.

\section{SECTION III: TREATMENT OF ASYMPTOMATIC ADULT OSA PATIENTS}

Question

Does treatment of asymptomatic adult OSA patients improve health outcomes?

\section{Introduction}

It is generally well accepted that symptomatic patients with OSAS should be offered a trial of therapy to improve sleepiness (1). Whether asymptomatic patients (ie, without daytime sleepiness) should be treated is a more controversial issue. This is important because a substantial proportion of patients will not complain of sleepiness (2). Hypertension and endothelial dysfunction are more prevalent in patients with OSAS than in controls $(3,4)$. Some have argued that
TABLE III-1

Literature search results: Study characteristics

\begin{tabular}{|c|c|c|c|c|}
\hline $\begin{array}{l}\text { Author } \\
\text { (ref), year }\end{array}$ & $\begin{array}{l}\text { Inclusion } \\
\text { criteria }\end{array}$ & $\begin{array}{l}\text { Study } \\
\text { duration }\end{array}$ & Intervention & Outcomes \\
\hline $\begin{array}{l}\text { Barbe } \\
\text { et al } \\
(6), \\
2001\end{array}$ & $\begin{array}{l}\mathrm{AHI}>30 \\
\mathrm{ESS} \leq 10 \\
\text { (55 patients) }\end{array}$ & $\begin{array}{l}6 \text { weeks CPAP } \\
\text { versus sham } \\
\text { CPAP }\end{array}$ & $24 \mathrm{~h} \mathrm{DBP}$ & $\begin{array}{c}3 \mathrm{mmHg} \text { reduction } \\
\text { compared with } \\
\text { control }(\mathrm{P}>0.2) \\
1 \mathrm{mmHg} \text { reduction } \\
(\mathrm{P}>0.2)\end{array}$ \\
\hline $\begin{array}{l}\text { Robinson } \\
\text { et al } \\
\text { (7), } \\
2008\end{array}$ & $\begin{array}{l}4 \% \text { DI }>10 / h \\
\text { ESS }<10 \\
\text { Hypertension } \\
\text { (35 patients) }\end{array}$ & $\begin{array}{l}2 \text { weeks CPAP } \\
\text { versus sham } \\
\text { (crossover) }\end{array}$ & $\begin{array}{l}24 \mathrm{~h} \mathrm{mBP} \\
24 \mathrm{~h} \text { SBP } \\
24 \mathrm{~h} \mathrm{DBP}\end{array}$ & $\begin{array}{l}0.74 \mathrm{mmHg} \text { reduction } \\
0.1 \mathrm{mmHg} \text { reduction } \\
1.81 \mathrm{mmHg} \text { reduction } \\
(P>0.59)\end{array}$ \\
\hline $\begin{array}{l}\text { Barbe } \\
\text { et al } \\
(8), \\
2010\end{array}$ & $\begin{array}{l}\text { AHI }>19 \\
\text { ESS }<11 \\
\text { Hypertensive } \\
\text { (359 patients) }\end{array}$ & $\begin{array}{l}12 \text { months CPAP } \\
\text { versus } \\
\text { conservative }\end{array}$ & SBP & $\begin{array}{l}1.89 \mathrm{mmHg} \\
\text { reduction }(P=0.065) \\
2.19 \mathrm{mmHg} \text { reduction } \\
(P=0.0008)\end{array}$ \\
\hline
\end{tabular}

AHI Apnea/hypopnea index; BP Blood pressure; CPAP Continuous positive airway pressure; DBP Diastolic BP; DI Desaturation index; ESS Epworth Sleepiness Scale; $\mathrm{mBP}$ Mean BP; ref Reference; SBP Systolic BP

therapy should be considered in asymptomatic OSA patients to improve future adverse clinical outcomes, especially with respect to preventing cardiovascular and cerebrovascular events.

The other point to consider is that the blood pressure response to therapy may be greater in symptomatic than in asymptomatic patients (5). Therefore, extrapolating studies of symptomatic patients with OSAS to asymptomatic patients may not be appropriate.

A systematic review to address this question was conducted and the guideline was subsequently updated. The committee specifically focused on RCTs of asymptomatic adult patients with OSA. Studies of patients with HF were excluded because they may be a very different population.

\section{Results}

Literature search: A total of 165 citations were identified in the literature search. After a review of the abstracts and relevant articles, only two $(6,7)$ met the inclusion criteria. A third study of relevance (8) was published after the search was completed but is included (Table III-1).

The committee focused on blood pressure reduction as the main outcome of interest. Two of the studies $(6,7)$ were modestly sized ( $n=55$ and $n=35$ patients, respectively), short duration RCTs that used sham CPAP. Although there was no significant impact on blood pressure, the small sample sizes may have reduced the power of the studies to detect a meaningful clinical difference. Indeed, the magnitude of blood pressure reduction in these two trials was genearally similar to that found in OSA patients treated with CPAP $(9,10)$. The third study (8) was the largest, and included 359 nonsleepy (Epworth Sleepiness Scale [ESS] score lower than than 11) hypertensive patients with moderate to severe OSA (AHI greater than $19 / \mathrm{h}$ ) randomly assigned to CPAP or control for 12 months. In this study, CPAP reduced systolic and diastolic blood pressure compared with controls, but the overall effect was fairly modest (1.89 $\mathrm{mmHg}$ and $2.19 \mathrm{mmHg}$, respectively). The impact of CPAP on blood pressure was greater in patients who used CPAP for more than $5.65 \mathrm{~h} /$ night $(3 \mathrm{mmHg}$ to $4 \mathrm{mmHg}$ reduction in blood pressure).

Other outcomes examined in these trials included objective and subjective measures of sleepiness. In the first study by Barbe et al (6), there was no significant impact on these outcomes. In the study by Robinson et al (7), there was a significant reduction in subjective (but not objective) sleepiness. In the most recent study by Barbe et al (8), CPAP significantly reduced ESS scores. 
The committee did not identify any RCTs studying clinical (eg, heart attacks or strokes) or safety (eg, motor vehicle collision) outcomes.

\section{Discussion}

Overall, there is very little evidence to inform this issue. There may be a potential benefit from treatment, given that treatment improves sleep fragmentation and desaturation. Results of studies in symptomatic OSAS patients suggest a benefit in terms of blood pressure reduction and other biomarkers of cardiovascular risk. Furthermore, prospective observational studies have shown that the use of CPAP reduces rates of cardiovascular events.

However, there are only three RCTs that have specifically addressed asymptomatic OSA patients. Two of the studies $(6,7)$ were negative, but had small sample sizes; therefore, a clinically important benefit cannot be excluded. The largest study (8) demonstrated a modest reduction in blood pressure in hypertensive patients.

Clearly, more data in this area are required. Ideally, these should include larger and longer RCTs studying a variety of clinical and intermediate end points. A number of RCTs in this area (eg, MOSAIC) are ongoing, and more data should be available in the near future.

\section{Question \#3}

Does treatment of asymptomatic adult OSA patients improve health outcomes?

\section{Recommendations}

The following recommendation is based on limited evidence and the consensus of the sleep apnea expert panel:

1. Treatment should be considered in asymptomatic patients with significant cardiovascular disease (including hypertension), especially if the AHI is $19 / \mathrm{h}$ or greater. (Grade of recommendation: $2 \mathrm{C}$ )

\section{REFERENCES}

1. Patel SR, White DP, Malhotra A, Stanchina M, Ayas NT. The effect of CPAP therapy on subjective and objective sleepiness in obstructive sleep apnea: A meta-analysis of randomized controlled trials. Arch Intern Med 2003;163:565-71.

2. Young T, Palta M, Dempsey J, Skatrud J, Weber S, Badr S. The occurrence of sleep disordered breathing among middle-aged adults. N Engl J Med 1993;32:1230-5.

3. Peppard PE, Young T, Palta M, Skatrud J. Prospective study of the association between sleep disordered breathing and hypertension. N Engl J Med 2000;11;342:1378-84.

4. Kato M, Roberts-Thomson P, Phillips BG, et al. Impairment of endothelium-dependent vasodilation of resistance vessels in patients with obstructive sleep apnea. Circulation 2000;21;102:2607-10.

5. Robinson GV, Smith DM, Langford BA, Davies RJ, Stradling JR. Continuous positive airway pressure does not reduce blood pressure in nonsleepy hypertensive OSA patients. Eur Respir J 2006;27:1229-35.

6. Barbe F, Mayoralas LR, Duran J, et al. Treatment with continuous positive airway pressure is not effective in patients with sleep apnea but no daytime sleepiness. A randomized, controlled trial. Ann Intern Med 2001;134:1015-23.

7. Robinson GV, Langford BA, Smith DM, Stradling JR. Predictors of blood pressure fall with continuous positive airway pressure (CPAP) treatment of obstructive sleep apnoea (OSA). Thorax 2008;63:855-9.

8. Barbe F, Duran-Cantolla J, Capote F, et al. Long term effects of continuous positive airway pressure in hypertensive patients with sleep apnea. Am J Respir Crit Care Med 2010;181:718-26.

9. Alajmi M, Mulgrew AT, Fox J, et al. The impact of continuous positive airway pressure (CPAP) therapy on blood pressure (BP) in patients with obstructive sleep apnea (OSA): A meta-analysis of randomized controlled trials. Lung 2007;185:67-72.

10. Haentjens P, Van Meerhaeghe A, Moscariello A, et al. The impact of continuous positive airway pressure on blood pressure in patients with obstructive sleep apnea syndrome: Evidence from a meta-analysis of placebo-controlled randomized trials. Arch Intern Med 2007;23;167:757-64.

\section{SECTION IV: TREATMENT WITH CONVENTIONAL CPAP COMPARED WITH APAP}

\section{Question}

Do OSAS patients benefit more from using APAP than from using CPAP?

\section{Introduction}

CPAP is the treatment of choice for OSAS. The optimal pressure level is ideally determined manually during in-laboratory sleep recording. APAP devices that automatically adjust the pressure level in response to the presence or absence of identified obstructive breathing disorders have been developed. The theoretical ability of these machines to continuously adapt pressure settings to ventilatory needs led to the concept that it could not only replace conventional CPAP (preventing the need for formal CPAP titration) but also improve treatment adherence and reduce side effects. On the other hand, APAP is not recommended for use in patients with cardiopulmonary or neuromuscular disease, or when sleep disordered breathing is not exclusively obstructive (eg, central apnea and hypoventilation). The 2006 CTS recommendations concluded that no benefits had been demonstrated with the use of APAP machines compared with conventional CPAP. The present work is an update of this important clinical question.

\section{Results}

Literature search characteristics: The literature search included various types of studies that encompassed patients with OSA, used CPAP as the intervention and compared it with APAP. Outcomes examined included the following: mortality, morbidity, arterial pressure, diabetes, sympathetic nervous system activity, sleep fragmentation, snoring, AHI, CSAS, oxygen saturation, sleepiness, QoL, CPAP compliance and CPAP choice.

Twenty-one studies were deemed eligible for inclusion in the systematic review of the literature. Table IV-1 summarizes the literature search results. One study was a meta-analysis, while the other 20 were prospective RCTs. These studies can be divided into two categories depending on the goal of the APAP trial. One category of use for APAP can be aimed at determining the optimal pressure setting during an ambulatory titration procedure and subsequently setting this pressure on a conventional fixed machine. Alternatively, it can also be used as a first-line treatment for sleep apnea, thus replacing fixedpressure CPAP therapy. Outcomes of interest included AHI, ESS/ objective daytime sleepiness, mean positive pressure level, treatment adherence, QoL, treatment preference and side effects.

\section{Study quality}

Seven RCTs assessed APAP used as a titration tool (1-7), while 13 RCTs evaluated APAP used as a treatment tool. As shown in Table IV-1, the size of the RCTs varied widely between studies (12 to 360 patients). One-half $(\mathrm{n}=12)$ of the trials used a crossover design. Patients were assessed after six months (8), three months $(1,2,5,9)$, two months (10-14), six weeks $(6,15)$, one month (16-20), one week ( 7$)$, and one night (3). In the majority of studies, subjects were exposed to CPAP before entry into their experimental arm (previous CPAP treatment or CPAP titration). Inclusion criteria widely varied from one study to another, but chronic cardiopulmonary disease (ie, COPD, restrictive chest disorders, congestive HF) and hypnotics/narcotics intake represented exclusion criteria in the majority of them.

\section{Outcomes}

In both study categories (ie, APAP as a titration or treatment tool), the majority of enrolled patients can be classified as having severe OSA according to mean AHI values.

APAP as a titration tool: APAP titration was generally found to be as effective as in-laboratory CPAP titration in normalizing AHI, and in improving diurnal symptoms and QoL. This method of titration is not associated with systematic differences compared with in-laboratory titration in terms of pressure recommendation and treatment adherence. The cost-effectiveness of APAP titration was demonstrated in 
TABLE IV-1

\begin{tabular}{|c|c|c|c|c|c|c|c|c|}
\hline \multirow[b]{3}{*}{$\begin{array}{l}\text { Author } \\
\text { (ref), year }\end{array}$} & \multirow[b]{3}{*}{ Study type } & \multirow[b]{3}{*}{$\mathbf{n}$} & \multicolumn{6}{|c|}{ Outcomes } \\
\hline & & & 1 & 2 & 3 & 4 & 5 & 6 \\
\hline & & & $\begin{array}{c}\text { Apnea + } \\
\text { hypopnea index }\end{array}$ & $\begin{array}{c}\text { ESS/objective } \\
\text { daytime } \\
\text { sleepiness }\end{array}$ & $\begin{array}{l}\text { Mean positive } \\
\text { pressure level }\end{array}$ & $\begin{array}{l}\text { Treatment } \\
\text { adherence }\end{array}$ & $\begin{array}{l}\text { Quality } \\
\text { of life }\end{array}$ & $\begin{array}{c}\text { Treatment } \\
\text { preference and } \\
\text { side effects }\end{array}$ \\
\hline $\begin{array}{l}\text { Ayas et al } \\
(21), 2004\end{array}$ & $\begin{array}{l}\text { Meta-analysis of } 9 \text { RCTs } \\
\text { comparing CPAP and APAP } \\
\text { published between } 1980 \text { and } \\
2003\end{array}$ & 282 & $\begin{array}{l}\text { No difference } \\
\text { between CPAP } \\
\text { and APAP }\end{array}$ & $\begin{array}{l}\text { No difference } \\
\text { between CPAP } \\
\text { and APAP }\end{array}$ & $\begin{array}{l}\text { Lower mean } \\
\text { pressure level } \\
\text { with APAP } \\
\left(2.2 \mathrm{cmH}_{2} \mathrm{O}\right. \\
[95 \% \mathrm{Cl} 1.9-2.5])\end{array}$ & $\begin{array}{l}\text { No difference } \\
\text { between CPAP } \\
\text { and APAP }\end{array}$ & - & - \\
\hline $\begin{array}{l}\text { Hukins (10), } \\
2004\end{array}$ & $\begin{array}{l}\text { RCT comparing follow-up of } \\
\text { patients at } 2 \text { months } \\
\text { undergoing APAP or CPAP } \\
\text { treatment (crossover) }\end{array}$ & 55 & - & $\begin{array}{l}\text { No difference } \\
\text { between CPAP } \\
\text { and APAP }\end{array}$ & $\begin{array}{l}\text { Lower median } \\
\text { and 95th } \\
\text { percentile with } \\
\text { APAP }\end{array}$ & $\begin{array}{l}\text { No difference } \\
\text { between CPAP } \\
\text { and APAP. Higher } \\
\text { adherence with } \\
\text { APAP in patients } \\
\text { reporting side } \\
\text { effects }\end{array}$ & $\begin{array}{l}\text { No difference } \\
\text { between } \\
\text { CPAP and } \\
\text { APAP } \\
\text { (SF-36) }\end{array}$ & $\begin{array}{l}\text { No preference. } \\
\text { Fewer side } \\
\text { effects with } \\
\text { APAP }\end{array}$ \\
\hline $\begin{array}{l}\text { Hussain et al } \\
(16), 2004\end{array}$ & $\begin{array}{l}\text { RCT comparing follow-up of } \\
\text { patients at } 1 \text { month undergoing } \\
\text { APAP or CPAP treatment } \\
\text { (crossover) }\end{array}$ & 10 & $\begin{array}{l}\text { No difference } \\
\text { between CPAP } \\
\text { and APAP }\end{array}$ & $\begin{array}{l}\text { No difference } \\
\text { between CPAP } \\
\text { and APAP }\end{array}$ & $\begin{array}{l}\text { No difference } \\
\text { between CPAP } \\
\text { and APAP }\end{array}$ & $\begin{array}{l}\text { No difference } \\
\text { between CPAP } \\
\text { and APAP }\end{array}$ & - & $\begin{array}{l}\text { Preference for } \\
\text { fixed CPAP }\end{array}$ \\
\hline $\begin{array}{l}\text { Masa et al } \\
(1), 2004\end{array}$ & $\begin{array}{l}\text { RCT comparing follow-up of } \\
\text { patients at } 3 \text { months } \\
\text { undergoing predicted formula, } \\
\text { automatic or manual CPAP } \\
\text { titration (parallel groups) }\end{array}$ & 360 & $\begin{array}{l}\text { No difference } \\
\text { among the } \\
3 \text { titration } \\
\text { modes }\end{array}$ & $\begin{array}{l}\text { No difference } \\
\text { among the } \\
3 \text { titration } \\
\text { modes }\end{array}$ & $\begin{array}{l}\text { No difference } \\
\text { among the } \\
3 \text { titration } \\
\text { modes }\end{array}$ & $\begin{array}{l}\text { No difference } \\
\text { among the } \\
3 \text { titration } \\
\text { modes }\end{array}$ & $\begin{array}{l}\text { Lower } \\
\text { improvement } \\
\text { in SF-36 with } \\
\text { APAP }\end{array}$ & $\begin{array}{l}\text { No difference } \\
\text { in side effects }\end{array}$ \\
\hline $\begin{array}{l}\text { Lloberes } \\
\text { et al (2), } \\
2004\end{array}$ & $\begin{array}{l}\text { RCT comparing follow-up of } \\
\text { patients at } 3 \text { months } \\
\text { undergoing nocturnal or } \\
\text { diurnal (automatic or manual) } \\
\text { CPAP titration (parallel groups) }\end{array}$ & 93 & - & $\begin{array}{l}\text { No difference } \\
\text { between } \\
\text { automatic and } \\
\text { manual titration }\end{array}$ & $\begin{array}{l}\text { Effective } \\
\text { pressure higher } \\
\text { during automatic } \\
\text { titration }\end{array}$ & $\begin{array}{l}\text { No difference } \\
\text { between automatic } \\
\text { and manual } \\
\text { titration }\end{array}$ & - & $\begin{array}{l}\text { No difference } \\
\text { in side effects }\end{array}$ \\
\hline $\begin{array}{l}\text { Noseda et al } \\
(11), 2004\end{array}$ & $\begin{array}{l}\text { RCT comparing follow-up at } \\
8 \text { weeks of patients with high } \\
\text { pressure variability on APAP } \\
\text { treated with APAP or CPAP } \\
\text { (crossover) }\end{array}$ & 24 & $\begin{array}{l}\text { No difference } \\
\text { between CPAP } \\
\text { and APAP }\end{array}$ & Lower with APAP & $\begin{array}{l}\text { No difference } \\
\text { between CPAP } \\
\text { and APAP }\end{array}$ & $\begin{array}{l}\text { No difference } \\
\text { between CPAP } \\
\text { and APAP }\end{array}$ & - & $\begin{array}{l}\text { Preference for } \\
\text { APAP }\end{array}$ \\
\hline $\begin{array}{l}\text { Marrone } \\
\text { et al (17), } \\
2004\end{array}$ & $\begin{array}{l}\text { RCT comparing follow-up of } \\
\text { patients at } 1 \text { month undergoing } \\
\text { APAP or CPAP treatment } \\
\text { (crossover) }\end{array}$ & 22 & - & $\begin{array}{l}\text { No difference } \\
\text { between CPAP } \\
\text { and APAP }\end{array}$ & $\begin{array}{l}\text { No difference } \\
\text { between CPAP } \\
\text { and APAP }\end{array}$ & $\begin{array}{l}\text { No difference } \\
\text { between CPAP } \\
\text { and APAP. Higher } \\
\text { observance with } \\
\text { APAP in patients } \\
\text { preferring APAP }\end{array}$ & - & $\begin{array}{l}\text { Preference for } \\
\text { APAP. } \\
\text { No difference } \\
\text { in side effects }\end{array}$ \\
\hline $\begin{array}{l}\text { Resta et al } \\
(18), 2004\end{array}$ & $\begin{array}{l}\text { RCT comparing follow-up of } \\
\text { patients at } 1 \text { month undergoing } \\
\text { APAP or CPAP treatment } \\
\text { (crossover) }\end{array}$ & 20 & $\begin{array}{l}\text { No difference } \\
\text { between CPAP } \\
\text { and APAP }\end{array}$ & $\begin{array}{l}\text { No difference } \\
\text { between CPAP } \\
\text { and APAP }\end{array}$ & $\begin{array}{l}\text { No difference } \\
\text { between CPAP } \\
\text { and APAP }\end{array}$ & - & - & - \\
\hline $\begin{array}{l}\text { Stammnitz } \\
\text { et al (3), } \\
2004\end{array}$ & $\begin{array}{l}\text { RCT comparing } 1 \text { night of } \\
\text { treatment with CPAP or } \\
3 \text { different APAP (crossover) }\end{array}$ & 12 & $\begin{array}{l}\text { Remained } \\
\text { abnormal in up } \\
\text { to } 50 \% \text { of } \\
\text { patients with } \\
\text { one APAP } \\
\text { apparatus }\end{array}$ & - & $\begin{array}{l}\text { Lower with } 2 \text { of } \\
\text { the APAP } \\
\text { machines } \\
\text { compared with } \\
\text { CPAP }\end{array}$ & - & - & - \\
\hline $\begin{array}{l}\text { Nussbaumer } \\
\text { et al (19), } \\
2006\end{array}$ & $\begin{array}{l}\text { RCT comparing follow-up of } \\
\text { patients at } 1 \text { month undergoing } \\
\text { APAP or CPAP treatment } \\
\text { (crossover) }\end{array}$ & 30 & $\begin{array}{l}\text { No difference } \\
\text { between CPAP } \\
\text { and APAP }\end{array}$ & $\begin{array}{l}\text { No difference } \\
\text { between CPAP } \\
\text { and APAP } \\
\text { (ESS, Osler) }\end{array}$ & $\begin{array}{l}\text { Lower with } \\
\text { APAP }\end{array}$ & $\begin{array}{l}\text { No difference } \\
\text { between CPAP } \\
\text { and APAP }\end{array}$ & - & $\begin{array}{l}\text { Preference for } \\
\text { APAP. Fewer } \\
\text { side effects } \\
\text { with APAP }\end{array}$ \\
\hline $\begin{array}{l}\text { Cross et al } \\
(4), 2006\end{array}$ & $\begin{array}{l}\text { RCT comparing follow-up of } \\
\text { patients at } 3 \text { months } \\
\text { undergoing automatic (home) } \\
\text { or manual CPAP titration } \\
\text { (parallel groups) }\end{array}$ & 200 & - & $\begin{array}{l}\text { No difference } \\
\text { between in-lab } \\
\text { and home } \\
\text { titration } \\
\text { (ESS, Osler) }\end{array}$ & $\begin{array}{l}\text { No difference in } \\
\text { effective } \\
\text { pressure } \\
\text { between in-lab } \\
\text { and home } \\
\text { titration }\end{array}$ & $\begin{array}{l}\text { No difference } \\
\text { between in-lab and } \\
\text { home titration }\end{array}$ & $\begin{array}{l}\text { No difference } \\
\text { between } \\
\text { in-lab and } \\
\text { home titration } \\
\text { (FOSQ, SF-36) }\end{array}$ & - \\
\hline
\end{tabular}




\begin{tabular}{|c|c|c|c|c|c|c|c|c|}
\hline \multirow[b]{3}{*}{$\begin{array}{l}\text { Author } \\
\text { (ref), year }\end{array}$} & \multirow[b]{3}{*}{ Study type } & \multirow[b]{3}{*}{$\mathrm{n}$} & \multicolumn{6}{|c|}{ Outcomes } \\
\hline & & & 1 & 2 & 3 & 4 & 5 & 6 \\
\hline & & & $\begin{array}{c}\text { Apnea + } \\
\text { hypopnea index }\end{array}$ & $\begin{array}{l}\text { ESS/objective } \\
\text { daytime } \\
\text { sleepiness }\end{array}$ & $\begin{array}{l}\text { Mean positive } \\
\text { pressure level }\end{array}$ & $\begin{array}{l}\text { Treatment } \\
\text { adherence }\end{array}$ & $\begin{array}{l}\text { Quality } \\
\text { of life }\end{array}$ & $\begin{array}{c}\text { Treatment } \\
\text { preference and } \\
\text { side effects }\end{array}$ \\
\hline $\begin{array}{l}\text { Nolan et al } \\
(20), 2006\end{array}$ & $\begin{array}{l}\text { RCT comparing efficiency of } \\
1 \text { month with } 3 \text { different APAP } \\
\text { machines (crossover) }\end{array}$ & 27 & $\begin{array}{l}\text { No difference } \\
\text { among the } \\
3 \text { apparatuses }\end{array}$ & $\begin{array}{l}\text { No difference } \\
\text { among the } \\
3 \text { apparatuses }\end{array}$ & $\begin{array}{l}\text { Lower with APAP } \\
\text { than with } \\
\text { previous CPAP } \\
\text { with differences } \\
\text { between APAP } \\
\text { machines }\end{array}$ & $\begin{array}{l}\text { Lower with } 1 \text { APAP } \\
\text { machine compared } \\
\text { with the } 2 \text { others }\end{array}$ & $\begin{array}{l}\text { No difference } \\
\text { among the } \\
3 \text { apparatuses }\end{array}$ & $\begin{array}{l}\text { No difference } \\
\text { in preference } \\
\text { nor in side } \\
\text { effects }\end{array}$ \\
\hline $\begin{array}{l}\text { Nolan et al } \\
(12), 2007\end{array}$ & $\begin{array}{l}\text { RCT comparing efficiency of } \\
2 \text { months with APAP or CPAP } \\
\text { (crossover) }\end{array}$ & 29 & $\begin{array}{l}\text { No difference } \\
\text { between CPAP } \\
\text { and APAP }\end{array}$ & $\begin{array}{l}\text { No difference } \\
\text { between CPAP } \\
\text { and APAP }\end{array}$ & Lower with APAP & $\begin{array}{l}\text { No difference } \\
\text { between CPAP } \\
\text { and APAP }\end{array}$ & - & $\begin{array}{l}\text { No difference } \\
\text { in preference } \\
\text { nor in side } \\
\text { effects }\end{array}$ \\
\hline $\begin{array}{l}\text { Fietze et al } \\
(15), 2007\end{array}$ & $\begin{array}{l}\text { RCT comparing follow-up of } \\
\text { patients at } 6 \text { weeks } \\
\text { undergoing APAP or CPAP } \\
\text { treatment (parallel groups) }\end{array}$ & 21 & $\begin{array}{l}\text { No difference } \\
\text { between CPAP } \\
\text { and APAP }\end{array}$ & $\begin{array}{l}\text { No difference } \\
\text { between CPAP } \\
\text { and APAP }\end{array}$ & $\begin{array}{l}\text { No difference } \\
\text { between CPAP } \\
\text { and APAP }\end{array}$ & $\begin{array}{l}\text { No difference } \\
\text { between CPAP } \\
\text { and APAP }\end{array}$ & $\begin{array}{l}\text { No difference } \\
\text { between } \\
\text { CPAP and } \\
\text { APAP (SF-36) }\end{array}$ & - \\
\hline $\begin{array}{l}\text { Patruno et al } \\
\text { (9), } 2007\end{array}$ & $\begin{array}{l}\text { RCT comparing follow-up of } \\
\text { patients at } 3 \text { months } \\
\text { undergoing APAP or CPAP } \\
\text { treatment (parallel groups) }\end{array}$ & 31 & $\begin{array}{l}\text { RDI higher with } \\
\text { APAP }\end{array}$ & - & - & $\begin{array}{l}\text { No difference } \\
\text { between CPAP } \\
\text { and APAP }\end{array}$ & - & - \\
\hline $\begin{array}{l}\text { Mulgrew } \\
\text { et al (5), } \\
2007\end{array}$ & $\begin{array}{l}\text { RCT comparing follow-up of } \\
\text { patients at } 3 \text { months } \\
\text { undergoing ambulatory or } \\
\text { in-lab investigation and CPAP } \\
\text { pressure setting (parallel } \\
\text { groups) }\end{array}$ & 68 & $\begin{array}{l}\text { No difference } \\
\text { between the } \\
2 \text { investigation/ } \\
\text { CPAP pressure } \\
\text { setting modes }\end{array}$ & $\begin{array}{l}\text { No difference } \\
\text { between the } \\
2 \text { investigation/ } \\
\text { CPAP pressure } \\
\text { setting modes }\end{array}$ & $\begin{array}{l}\text { No difference } \\
\text { between the } \\
2 \text { investigation/ } \\
\text { CPAP pressure } \\
\text { setting modes }\end{array}$ & $\begin{array}{l}\text { Higher in the } \\
\text { ambulatory group }\end{array}$ & $\begin{array}{l}\text { No difference } \\
\text { between the } \\
2 \text { investigation/ } \\
\text { CPAP } \\
\text { pressure } \\
\text { setting modes } \\
\text { (SAQLI) }\end{array}$ & 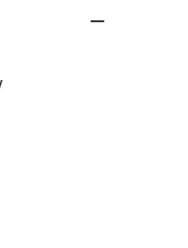 \\
\hline $\begin{array}{l}\text { Galetke et al } \\
(13), 2008\end{array}$ & $\begin{array}{l}\text { RCT comparing follow-up of } \\
\text { patients at } 8 \text { weeks } \\
\text { undergoing APAP or CPAP } \\
\text { treatment (crossover) }\end{array}$ & 20 & $\begin{array}{l}\text { No difference } \\
\text { between CPAP } \\
\text { and APAP }\end{array}$ & $\begin{array}{l}\text { No difference } \\
\text { between CPAP } \\
\text { and APAP }\end{array}$ & $\begin{array}{l}\text { No difference } \\
\text { between CPAP } \\
\text { and APAP }\end{array}$ & $\begin{array}{l}\text { No difference } \\
\text { between CPAP } \\
\text { and APAP }\end{array}$ & - & $\begin{array}{l}\text { Preference for } \\
\text { APAP }\end{array}$ \\
\hline $\begin{array}{l}\text { Series et al } \\
(7), 2008\end{array}$ & $\begin{array}{l}\text { RCT comparing pressure } \\
\text { recommendation with } \\
3 \text { different APAP machines } \\
\text { (crossover) }\end{array}$ & 16 & $\begin{array}{l}\text { No difference } \\
\text { among the } \\
3 \text { machines }\end{array}$ & $\begin{array}{l}\text { No difference } \\
\text { among the } \\
3 \text { machines }\end{array}$ & $\begin{array}{l}\text { Significant } \\
\text { difference in the } \\
\text { variance of } \\
\text { recommended } \\
\text { pressure setting } \\
\text { among the } \\
3 \text { machines }\end{array}$ & $\begin{array}{l}\text { No difference } \\
\text { among the } \\
3 \text { machines }\end{array}$ & - & - \\
\hline $\begin{array}{l}\text { To et al (14), } \\
2008\end{array}$ & $\begin{array}{l}\text { RCT comparing follow-up of } \\
\text { patients at } 8 \text { weeks } \\
\text { undergoing APAP or CPAP } \\
\text { treatment (crossover) }\end{array}$ & 41 & $\begin{array}{l}\text { Normal in both } \\
\text { groups but } \\
\text { lower with } \\
\text { CPAP }\end{array}$ & $\begin{array}{l}\text { No difference } \\
\text { between APAP } \\
\text { and CPAP }\end{array}$ & Lower with APAP & Higher with APAP & $\begin{array}{l}\text { Similarly } \\
\text { improved with } \\
\text { APAP and } \\
\text { CPAP } \\
\text { (SAQLI) }\end{array}$ & $\begin{array}{l}\text { Higher } \\
\text { pressure } \\
\text { discomfort } \\
\text { with APAP, } \\
\text { higher mouth/ } \\
\text { nose dryness } \\
\text { with CPAP }\end{array}$ \\
\hline
\end{tabular}


one well-designed, well-powered study (4). However, there is evidence that differences in recommendations for pressure setting are observed among APAP machines depending on their algorithm of pressure response.

APAP as a treatment tool: Generally, the improvement in the measured outcomes of fixed CPAP and APAP is identical. The reduction in positive pressure level with APAP therapy is still inconsistently reported, and adherence to treatment between conventional CPAP and APAP rarely differ. As for APAP titration, there are machineto-machine differences in pressure behaviour. Limited data are available regarding the identification of subjects in whom APAP therapy would improve treatment outcomes (better observance in patients whose CPAP effective pressure is higher than $10 \mathrm{cmH}_{2} \mathrm{O}$, absence of influence of pressure variability). Noteworthy, the reduction in positive pressure level that is occasionally observed with APAP is not associated with an improvement in treatment observance nor with a preference for APAP devices. One study (9) evaluated the impact of treatment mode on cardiometabolic risk and found that APAP may be less effective than CPAP in preventing this risk.

\section{Discussion}

The usefulness of APAP was first described in 1993 by M BerthonJones. Its possible advantages were to continuously adapt the pressure setting to the patient's requirements, therefore allowing for pressure changes depending on conditions such as body/neck position, sleep stages, nasal obstruction and weight changes. The present review of the literature was built on the RCT published after the completion of the meta-analysis conducted by Ayas et al (21) in 2004. This study was considered to be very helpful in the present evaluation because it included an analysis of RCTs conducted between 1980 and 2003 that compared CPAP and APAP treatment. These RCTs emphasize the fact that recruited subjects often have severe sleep apnea and that participation in these studies requires the absence of many exclusion criteria. This is to be kept in mind when elaborating on the clinical applicability of APAP devices from a clinical standpoint. The general findings of these studies were that CPAP and APAP are equivalent in their ability to normalize breathing at night and to improve daytime sleepiness. It was also found that APAP allowed for a reduction in mean pressure, but was not accompanied by an improvement in adherence to CPAP treatment. Overall, treatment observance was not different between CPAP and APAP in $91.7 \%$ of the studies, which reported identical improvement in diurnal symptoms and QoL. Side effects were identical with APAP and CPAP in 50\% of studies, and occurred less frequently with APAP in the other studies.

Regarding the use of APAP as a titration tool, the present update confirms that APAP titration is generally as effective as in-laboratory CPAP titration in normalizing AHI, and in improving diurnal symptoms and QoL. No systematic difference in terms of pressure recommendation and treatment adherence was observed between automatic versus manual in-laboratory titration. However, there is evidence that APAP machines may differ in their pressure behaviour depending on signal processing, identification of breathing abnormalities and the algorithm of pressure response. Such differences are responsible for the large variance in recommendation for pressure setting among various APAP machines.

Concerning the use of APAP as a treatment tool, there is no systematic difference in the measured outcomes between fixed CPAP and APAP. As identified in the previous CTS report, APAP therapy only occasionally leads to a reduction in positive pressure level as a consequence of machine-to-machine differences in pressure behaviour. Furthermore, APAP treatment does not improve adherence to treatment in the OSAS population at large, nor is it usually preferred over conventional CPAP. Factors such as the need for high positive pressure level may be associated with a better adherence to APAP therapy, but there is a general lack of data regarding the identification of subjects who would particularly benefit from APAP therapy.
It should be noted that no study was designed to compare CPAP and APAP efficiency in patients poorly compliant to CPAP, or in those complaining of specific side effects after optimal adjustment of fixed CPAP treatment. Aside from the conventional outcomes examined in the majority of these RCTs, limited information is available regarding the impact of treatment mode on cardiometabolic risk. The results of one study (9) suggested that improvement in arterial pressure and in metabolic variables was less with APAP than with CPAP. Considering the differences in APAP machine responses, comparisons of different APAP apparatuses with respect to these risk factors are needed.

\section{Conclusion}

APAP can be considered to be an effective tool to determine pressure setting on an ambulatory basis. Such a strategy may be cost- and timeefficient compared with conventional in-laboratory CPAP titration. There is no clear demonstration of the systematic benefits of APAP as a treatment tool for OSAS when compared with standard CPAP. It is important to remember that the majority of studies completed with APAP included patients with severe OSAS and used strict exclusion criteria.

\section{Question \#4}

Do OSAS patients benefit more from using APAP than from using CPAP?

\section{Recommendations}

The following recommendations are based on limited evidence and the consensus of the sleep apnea expert panel:

1. Conventional CPAP at a fixed pressure is the primary treatment for patients with OSAS. (Grade of recommendation: 1B)

2. APAP is an alternative effective treatment to fixed CPAP for OSAS in the absence of comorbid diseases and conditions. (Grade of recommendation: 1B)

\section{REFERENCES}

1. Masa JF, Jimenez A, Duran J, et al. Alternative methods of titrating continuous positive airway pressure: A large multicenter study. Am J Respir Crit Care Med 2004;170:1218-24.

2. Lloberes P, Rodriguez B, Roca A, et al. Comparison of conventional nighttime with automatic or manual daytime CPAP titration in unselected sleep apnea patients: Study of the usefulness of daytime titration studies. Respir Med 2004;98:619-25.

3. Stammnitz A, Jerrentrup A, Penzel T, Peter JH, Vogelmeier C, Becker HF. Automatic CPAP titration with different self-setting devices in patients with obstructive sleep apnoea. Eur Respir J 2004;24:273-8.

4. Cross MD, Vennelle M, Engleman HM, et al. Comparison of CPAP titration at home or the sleep laboratory in the sleep apnea hypopnea syndrome. Sleep 2006;29:1451-5.

5. Mulgrew AT, Cheema R, Fleetham J, Ryan CF, Ayas NT. Efficacy and patient satisfaction with autoadjusting CPAP with variable expiratory pressure vs standard CPAP: A two-night randomized crossover trial. Sleep Breath 2007;11:31-7.

6. Berry RB, Hill G, Thompson L, McLaurin V. Portable monitoring and autotitration versus polysomnography for the diagnosis and treatment of sleep apnea. Sleep 2008;31:1423-31.

7. Series F, Plante J, Lacasse Y. Reliability of home CPAP titration with different automatic CPAP devices. Respir Res 2008;956.

8. Meurice J-C, Ingrand P, Portier F, et al. A multicentre trial of education strategies at CPAP induction in the treatment of severe sleep apnoea-hypopnoea syndrome. Sleep Med 2007;8:37-42.

9. Patruno V, Aiolfi S, Costantino G, et al. Fixed and autoadjusting continuous positive airway pressure treatments are not similar in reducing cardiovascular risk factors in patients with obstructive sleep apnea. Chest 2007;131:1393-9.

10. Hukins C. Comparative study of autotitrating and fixed-pressure CPAP in the home: A randomized, single-blind crossover trial. Sleep 2004:27:1512-7.

11. Noseda A, Kempenaers C, Kerkhofs M, Braun S, Linkowski P, Jann E. Constant vs auto-continuous positive airway pressure in patients with sleep apnea hypopnea syndrome and a high variability in pressure requirement. Chest 2004;126:31-7. 
12. Nolan GM, Doherty LS, McNicholas WT. Auto-adjusting versus fixed positive pressure therapy in mild to moderate obstructive sleep apnoea. Sleep 2007;30:189-94.

13. Galetke W, Anduleit N, Richter K, Stieglitz S, Randerath WJ. Comparison of automatic and continuous positive airway pressure in a night-by-night analysis: A randomized, crossover study. Respiration 2008;75:163-9.

14. To KW, Chan WC, Choo KL, Lam WK, Wong KK, Hui DS. A randomized cross-over study of auto-continuous positive airway pressure versus fixed-continuous positive airway pressure in patients with obstructive sleep apnoea. Respirology 2008;13:79-86.

15. Fietze I, Glos M, Moebus I, Witt C, Penzel T, Baumann G. Automatic pressure titration with APAP is as effective as manual titration with CPAP in patients with obstructive sleep apnea. Respiration 2007;74:279-86.

16. Hussain SF, Love L, Burt H, Fleetham JA. A randomized trial of auto-titrating CPAP and fixed CPAP in the treatment of obstructive sleep apnea-hypopnea. Respir Med 2004;98:330-3.

17. Marrone O, Resta O, Salvaggio A, Giliberti T, Stefano A, Insalaco G. Preference for fixed or automatic CPAP in patients with obstructive sleep apnea syndrome. Sleep Med 2004;5:247-51.

18. Resta O, Carratu P, Depalo A, et al. Effects of fixed compared to automatic CPAP on sleep in obstructive sleep apnoea syndrome. Monaldi Arch Chest Dis 2004;61:153-6.

19. Nussbaumer Y, Bloch KE, Genser T, Thurnheer R. Equivalence of autoadjusted and constant continuous positive airway pressure in home treatment of sleep apnea. Chest 2006;129:638-43.

20. Nolan GM, Ryan S, O'Connor TM, McNicholas WT. Comparison of three auto-adjusting positive pressure devices in patients with sleep apnoea. Eur Respir J 2006;28:159-64.

21. Ayas NT, Patel SR, Malhotra A, et al. Auto-titrating versus standard continuous positive airway pressure for the treatment of obstructive sleep apnea: Results of a meta-analysis. Sleep 2004;27:249-53.

\section{Question}

\section{SECTION V: BARIATRIC SURGERY}

Is bariatric surgery (eg, Roux-en-Y gastric bypass, biliopancreatic diversion, gastric banding or gastric balloon) an effective treatment strategy in obese patients with OSAS compared with standard care, CPAP, exercise and diet?

\section{Introduction}

Body weight and neck circumference are important factors in the pathogenesis of OSAS (1). Weight loss through dieting is associated with a significant increase in the volume of the retroglossal and retropalatal airway lumen (2). Furthermore, weight loss is well known to be associated with a reduction in sleep apnea severity. In a prospective community-based cohort study (3), obstructive sleep apnea severity increased or decreased by approximately $30 \%$ for a $10 \%$ increase or decrease, respectively, in body weight over a four-year period. These findings emphasize the importance of weight loss as a potential treatment option for OSAS in overweight or obese individuals. Bariatric surgery is the most effective method of sustained long-term weight reduction in morbidly obese individuals (4-6). The Obesity Canada Clinical Practice Guidelines Expert Panel (7) recommends that bariatric surgery be considered in the management of individuals who have failed to achieve satisfactory weight loss through other means, and who have either a body mass index (BMI) of greater than $40 \mathrm{~kg} / \mathrm{m}^{2}$, or a BMI of greater than $35 \mathrm{~kg} / \mathrm{m}^{2}$ and additional risk factors for the development of cardiovascular disease. Given the overlap between obesity and OSAS, and the documented benefits of weight loss on sleep apnea severity, it is logical to consider a therapeutic role for bariatric surgery in the management of some morbidly obese individuals with OSAS.

\section{Key evidence (Table V-1)}

Nineteen articles identified in the literature search were deemed eligible for inclusion in the systematic review to inform the section on the impact of bariatric surgery on OSA. Fifteen of these articles (comprising two systematic reviews, six prospective noncontrolled studies and seven retrospective studies) evaluated the efficacy of bariatric surgery on sleep apnea severity. Mortality from bariatric surgery was informed by four studies - one prospective controlled trial, one prospective noncontrolled trial and two retrospective controlled studies. There were no RCTs evaluating the impact of bariatric surgery on sleep apnea severity.

\section{Study characteristics}

There are no published RCTs evaluating the effect of bariatric surgery on OSAS severity. Three of four systematic reviews (4-6) focused on the general efficacy of bariatric surgery for weight loss and reduction in obesity-related comorbid conditions (rather than sleep apnea specifically). One systematic review (8) focused specifically on evaluating the efficacy of bariatric surgery as a treatment for sleep apnea. The latter study included a meta-analysis of the impact of bariatric surgery on OSAS severity which was, unlike the previous systematic reviews, limited to studies that provided PSG measurement of sleep apnea severity pre- and postbariatric surgery (9-20). An additional prospective, noncontrolled, single-site study involving 46 Asian patients undergoing laparoscopic-band surgery was recently published (21). One prospective, nonrandomized controlled study (22) and two retrospective controlled cohort studies $(23,24)$ evaluated long-term mortality after bariatric surgery, and one prospective, multicentre observational study evaluated 30-day mortality after bariatric surgery (25).

\section{Conclusions}

The average weight loss resulting from bariatric surgical procedures is significantly greater than that attained using conservative measures (22). In a meta-analysis of 22,094 patients undergoing bariatric surgery (5), weight loss after gastric banding was reported to be $28.6 \mathrm{~kg}$ (range $24.5 \mathrm{~kg}$ to $32.8 \mathrm{~kg}$ ) compared with $43.5 \mathrm{~kg}$ (range $38.8 \mathrm{~kg}$ to $48.1 \mathrm{~kg}$ ) for gastric bypass, and $46.4 \mathrm{~kg}(41.2 \mathrm{~kg}$ to $51.6 \mathrm{~kg})$ for biliopancreatic diversion. The corresponding changes in BMI were $10.4 \mathrm{~kg} / \mathrm{m}^{2}$ (range $9.3 \mathrm{~kg} / \mathrm{m}^{2}$ to $11.5 \mathrm{~kg} / \mathrm{m}^{2} ; 16.7 \mathrm{~kg} / \mathrm{m}^{2}\left(15.0 \mathrm{~kg} / \mathrm{m}^{2}\right.$ to $18.4 \mathrm{~kg} / \mathrm{m}^{2}$ ); and $18 \mathrm{~kg} / \mathrm{m}^{2}\left(16.6 \mathrm{~kg} / \mathrm{m}^{2}\right.$ to $\left.19.4 \mathrm{~kg} / \mathrm{m}^{2}\right)$ (Table V-II). This compares very favourably with the use of the antiobesity medications orlistat, sibutramine and rimonabant, which achieve average weight losses of $5 \mathrm{~kg}$ or less (26). Maximum weight loss is achieved one year postsurgery, which is followed by a minor weight gain; however, even 15 years after the date of surgery, a great majority of the weight loss is maintained $(4,6,22)$. The 30 -day mortality rate associated with bariatric surgery is acceptably low, varying from $0 \%$ to $0.3 \%$ for laparoscopic procedures (including Roux-en-Y gastric bypass ) to $2.1 \%$ for procedures performed by laparotomy (25). Importantly, however, long-term mortality figures for morbidly obese individuals undergoing bariatric surgery are significantly lower than those who are managed conservatively (22-24). Furthermore, obesity-related comorbidities other than sleep apnea (eg, hypertension, diabetes mellitus and hyperlipidemia) are also significantly reduced postbariatric surgery $(4,5,7,22)$. In a prospective, nonrandomized, controlled study (22), mortality was improved in the bariatric surgical group, and sleep apnea severity (measured only on a crude, subjective basis) was reduced. An earlier meta-analysis (5) of the impact of bariatric surgery on obstructive sleep apnea reported that $86 \%$ of patients "no longer needed CPAP treatment" after bariatric surgery; however, many of the studies included in that analysis did not report objective quantification of sleep apnea severity before and after the surgery. Indeed, although published studies in which sleep apnea severity was measured before and after bariatric surgery, substantial improvements in sleep apnea severity have generally been observed. However, there are exceptions, and the reported success rate for complete abolition of OSAS is quite variable. Furthermore, among patients who experienced abolition of OSAS postbariatric surgery, subsequent recurrence of OSAS without additional weight gain has been reported (20). In a meta-analysis of 12 studies involving 342 patients with OSAS who underwent PSG before and after bariatric surgery (8), the AHI fell from a mean of approximately 55 presurgery to 16 postsurgery, with a 
TABLE V-1

Literature search results

\begin{tabular}{|c|c|c|c|c|}
\hline Author (reference), year & Study type & Patients, $\mathrm{n}$ & Intervention & Follow-up period \\
\hline \multicolumn{5}{|l|}{ Systematic reviews } \\
\hline Greenburg et al (8), 2009 & Systematic review & 342 & Banding, RYGB, VBG, BPD & 3 months to 12 years \\
\hline Buchwald et al (5), 2004 & Systematic review & 22,094 (1195 with OSA) & Banding, bypass, gastroplasty, BPD & Variable \\
\hline Lettieri et al (20), 2008 & Prospective & 24 & Gastric banding & 12 months \\
\hline Haines et al (18), 2007 & Prospective & 101 & RYGB (50\% open, 50\% laparoscopic) & $\begin{array}{l}11 \text { months (range } 6 \text { to } \\
42 \text { months) }\end{array}$ \\
\hline Schueller and Weider (12), 2001 & Retrospective & 15 & $\mathrm{BPD}, \mathrm{VBG}$ & 12 to 144 months \\
\hline Rasheid et al (14), 2003 & Prospective & 11 & RYGB & 6 months \\
\hline Pillar et al (11), 1994 & Retrospective & 14 & Various & 7.5 years \\
\hline Charuzi et al (9), 1992 & Retrospective & 47 & RYGB, VBG & 12 to 84 months \\
\hline Guardiano et al (13), 2003 & Retrospective & 8 & RYGB & $28 \pm 20$ months \\
\hline Dixon et al (16), 2005 & Prospective & 25 & Laparoscopic band & $17.7 \pm 10$ months \\
\hline \multicolumn{5}{|l|}{ Mortality } \\
\hline Sjöström et al (22), 2007 & Prospective controlled & 4047 & Bypass, VBG, banding & 10.9 years \\
\hline Adams et al (23), 2007 & Retrospective controlled cohort & 9949 & RYGB & 7.1 years \\
\hline Perry et al (24), 2008 & Retrospective controlled cohort & $\begin{array}{c}10,593 \text { younger than } 65 \mathrm{yr} \\
1310 \text { older than } 65 \mathrm{yr}\end{array}$ & Various & 24 months \\
\hline LABS (25), 2009 & Prospective uncontrolled & 4776 & Laparoscopic band & 30 days \\
\hline
\end{tabular}

BPD Biliopancreatic diversion surgery; HG Horizontal gastroplasty; LABS Longitudinal Assessment of Bariatric Surgery Consortium; OSA Obstructive sleep apnea; RYGB Roue-en-Y gastric bypass surgery; VBG Vertical banded gastroplasty; yr Years of age

TABLE V-2

Outcomes

\begin{tabular}{|c|c|c|c|c|c|c|c|c|}
\hline \multirow{2}{*}{$\begin{array}{l}\text { Author } \\
\text { (ref), year }\end{array}$} & \multirow[b]{2}{*}{ Patients, n } & \multirow[b]{2}{*}{ Surgery } & \multicolumn{2}{|c|}{ Weight loss, mean (range) } & \multirow{2}{*}{$\begin{array}{c}\text { Change in BMI, } \\
\mathrm{kg} / \mathrm{m}^{2}\end{array}$} & \multirow{2}{*}{$\begin{array}{l}\% \text { Sleep apnea } \\
\text { resolved (range) }\end{array}$} & \multirow{2}{*}{$\begin{array}{l}\text { Mortality within } \\
30 \text { days post-op }\end{array}$} & \multirow{2}{*}{$\begin{array}{c}\text { Change in } \mathrm{AHI} \\
\text { postsurgery }\end{array}$} \\
\hline & & & $\%$ excess & kg & & & & \\
\hline \multirow{5}{*}{$\begin{array}{l}\text { Buchwald } \\
\text { et al (5), } \\
2004\end{array}$} & \multirow{5}{*}{$\begin{array}{l}22,094 \\
(n=1195 \text { for } \\
\text { OSA })\end{array}$} & Banding & $47.5(40.7-54.2)$ & $28.64(24.51-32.77)$ & $10.43(9.33-11.52)$ & $68.0(26.2-100)$ & $0.1 \%$ & NR \\
\hline & & Bypass & $61.6(56.7-66.5)$ & $43.48(38.82-48.14)$ & $16.7(14.98-18.43)$ & $94.8(91.5-98)$ & $0.5 \%$ & $31.6(19-44)$ \\
\hline & & Gastroplasty & $68.2(61.5-74.8)$ & $39.82(34.9-44.74)$ & $14.2(12.27-16.14)$ & $90.7(78.5-100)$ & $0.1 \%$ & NR \\
\hline & & BPD/switch & $70.1(66.3-73.9)$ & $46.39(41.2-51.58)$ & $17.99(16.59-19.4)$ & $71.2(34.5-100)$ & $1.1 \%$ & NR \\
\hline & & Overall & $61.2(58.1-64.4)$ & 39.71 (37.19-42.23 & $14.2(13.27-15.13)$ & 85.7 (79.2-92.2) & & $33.85(17-50)$ \\
\hline $\begin{array}{l}\text { Greenburg } \\
\text { et al (8), } \\
2009\end{array}$ & 349 & $\begin{array}{l}\text { Various } \\
\text { (RYGB, } \\
\text { Banding, } \\
\text { VBG, BPD) }\end{array}$ & NR & NR & $17.9(16.5-19.3)$ & $\begin{array}{l}25 \text { (38\% had } \mathrm{AHI} \\
<15 \text { at follow-up, } \\
\text { mean } \mathrm{AHI}=16)\end{array}$ & NR & $\begin{array}{l}38.2 \\
\quad(31.9-44.4)\end{array}$ \\
\hline $\begin{array}{l}\text { Haines et al } \\
(18), 2007\end{array}$ & $\begin{array}{l}101 \text { with ESS } \\
>6 \text { had OSA } \\
\text { on PSG }\end{array}$ & $\begin{array}{l}\text { RYGB }(50 \% \\
\text { open, } 50 \% \\
\text { lap) }\end{array}$ & Not reported & Not reported & $\begin{array}{l}56 \pm 1 \text { to } \\
38 \pm 1=18\end{array}$ & $\begin{array}{l}\text { Not reported; } 84 \\
\text { on CPAP before } \\
\text { sx, } 31 \text { after }\end{array}$ & $2 \%$ & $\begin{array}{l}36(51 \pm 4- \\
15 \pm 2)\end{array}$ \\
\hline $\begin{array}{r}\text { Adams et al } \\
\text { (23), } 2007\end{array}$ & 9949 & & & & & & $\begin{array}{l}40 \% \text { reduction in } \\
\text { overall mortality } \\
\text { (cardiac, dm2, } \\
\text { cancers) }\end{array}$ & 7.1 years \\
\hline $\begin{array}{l}\text { Perry et al } \\
(24), 2008\end{array}$ & $\begin{aligned} & 10,593<65 \mathrm{yr} \\
& 1310>65 \mathrm{yr} \\
& \text { FU } 2 \mathrm{yr}\end{aligned}$ & Various & & & & $\begin{array}{l}29.6 \text { to } 24.3 \\
\text { (absolute } \\
\text { change }=4.9 \text { ) }\end{array}$ & $1 \%-2 \%$ & NR \\
\hline $\begin{array}{r}\text { Lettieri et al } \\
(20), 2008\end{array}$ & $\begin{array}{l}118 \text { referred for } \\
\text { gastric } \\
\text { banding, } \\
25 \text { referred } \\
\text { for PSG first; } \\
24 \text { survived }\end{array}$ & Lap band & & & $\begin{array}{l}51 \pm 10.4 \text { to } \\
32.1 \pm 5.5\end{array}$ & $5 \%$ & & $\begin{array}{l}47.9 \pm 33.8 \text { to } \\
24.5 \pm 18.1 \\
\text { CPAP pressure } \\
11.5 \pm 3.6 \text { to } \\
8.4 \pm 2.1 \mathrm{cmH}_{2} \mathrm{O}\end{array}$ \\
\hline $\begin{array}{l}\text { Schueller and } \\
\text { Weider (12), } \\
2001\end{array}$ & 15 & $11 \mathrm{BPD}, 4 \mathrm{VBG}$ & & 54.7 & & $\begin{array}{l}\text { 10/11 BPD had } \\
\text { post-op AHI } \\
<20 ; 3 \text { of } 4 \text { VBG } \\
\text { had post-op } \\
\text { AHI >20) } 60 \%\end{array}$ & $0 \%$ & 96.9 to 11.3 \\
\hline
\end{tabular}


TABLE V-2 - CONTINUED

Outcomes

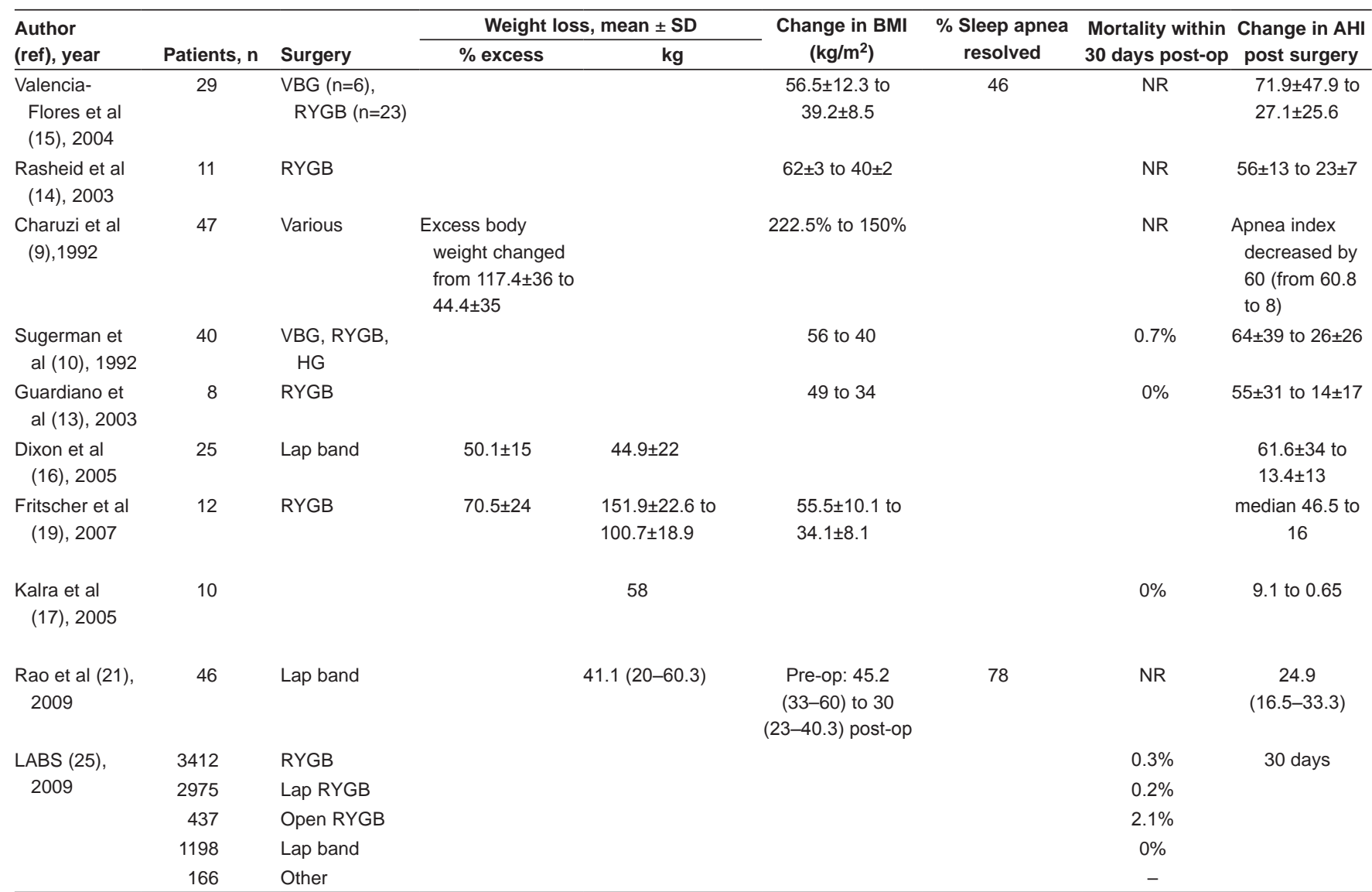

AHI Apnea/hypopnea index; BMI Body mass index; BPD Biliopancreatic diversion surgery; CPAP Continuous positive airway pressure; dm2 Type 2 diabetes melitus; ESS Epworth Sleepiness Scale; FU Follow-up; HG Horizontal gastroplasty; LABS Longitudinal Assessment of Bariatric Surgery Consortium; Lap Laparascopic; NR Not reported; OSA Obstructive sleep apnea; post-op Postoperative; Pre-op Preoperative; PSG Polysomnography; ref Reference; RYGB Roue-en-Y gastric bypass surgery; sx Surgery; VBG Vertical banded gastroplasty; yr Years of age

coincident mean reduction in BMI of approximately $18 \mathrm{~kg} / \mathrm{m}^{2}$. Thus, contrary to the implication from earlier systematic analyses that bariatric surgery obviated the need for continued treatment of OSAS, the most recent and comprehensive meta-analysis of bariatric surgical impact on sleep apnea severity suggests that the average AHI postbariatric surgery is consistent with moderately severe OSAS (8). Thus, patients are advised to remain on treatment for OSA after bariatric surgery and, if asymptomatic from the sleep apnea perspective after weight loss, to undergo diagnostic PSG to objectively evaluate sleep apnea severity before discontinuation of treatment.

There are no RCTs comparing medical (ie, diet and medication) therapy versus bariatric surgery for the management of OSAS in obese patients. However, based on available data demonstrating substantially greater weight loss after bariatric surgery, it is likely that medical management would be less effective as a strategy for treating OSA through weight reduction than bariatric surgery.

There is relatively little information available regarding changes in CPAP pressure requirement after weight loss postbariatric surgery; however, Greenburg et al (8) described an average pre- to postbariatric surgery pressure decrease of approximately $4 \mathrm{cmH}_{2} \mathrm{O}$ in patients still requiring CPAP.

Thus, limited available evidence suggests a survival benefit from bariatric surgery in morbidly obese individuals, and that the surgery is usually associated with improvement but not complete abolition of sleep disordered breathing.

\section{Question \#5}

Is bariatric surgery (Roux-en-Y gastric bypass, biliopancreatic diversion, gastric banding or gastric balloon) an effective treatment strategy in obese patients with obstructive sleep apnea compared with standard care, CPAP, exercise and diet?

\section{Recommendations}

The following recommendations are based on limited evidence from nonrandomized trials, and the consensus of the sleep apnea expert panel.

1. Bariatric (weight loss) surgery should be considered in the management of OSAS in morbidly obese patients (BMI of greater than $40 \mathrm{~kg} / \mathrm{m}^{2}$ ), and in those with a BMI of greater than $35 \mathrm{~kg} / \mathrm{m}^{2}$ who also have serious comorbid disease, after failure to lose weight or to maintain weight loss with dietary and lifestyle approaches (Grade of recommendation: 1C)

2. A diagnostic sleep study should be undertaken in asymptomatic patients after achievement of maximum weight loss (usually one-year postbariatric surgery), to re-evaluate OSAS severity, before abandoning CPAP or other treatment for OSAS. (Grade of recommendation: 2C)

\section{REFERENCES}

1. White DP. Pathogenesis of obstructive and central sleep apnea. Am J Respir Crit Care Med 2005;172:1363-70. 
2. Welch KC, Foster GD, Ritter CT, et al. A novel volumetric magnetic resonance imaging paradigm to study upper airway anatomy. Sleep 2002;25:532-42.

3. Peppard PE, Young T, Palta M, Dempsey J, Skatrud J. Longitudinal study of moderate weight change and sleep disordered breathing. JAMA 2000;284:3015-21.

4. Colquitt JL, Picot J, Loveman E, Clegg AJ. Surgery for obesity. Cochrane Database Syst Rev 2009;(2):CD003641.

5. Buchwald $\mathrm{H}$, Avidor $\mathrm{Y}$, Braunwald E, et al. Bariatric surgery: A systematic review and meta-analysis. JAMA 2004;292:1724-37.

6. Maggard MA, Shugarman LR, Suttorp M, et al. Meta-analysis: surgical treatment of obesity. Ann Intern Med 2005;142:547-59.

7. Lau DCW, Douketis JD, Morrison KM, Hramiak IM, Sharma AM, Ur E; for the Obesity Canada Clinical Practice Guidelines Expert Panel. 2006 Canadian clinical practice guidelines on the management and prevention of obesity in adults and children. CMAJ 2007;176(Suppl 8):S1-S13.

8. Greenburg DL, Lettieri CJ, Eliasson AH. Effects of surgical weight loss on measures of obstructive sleep apnea: A meta-analysis. Am J Med 2009;122:535-42.

9. Charuzi I, Lavie P, Peiser J, Peled R. Bariatric surgery in morbidly obese sleep-apnea patients: Short- and long-term follow-up. Am J Clin Nutr 1992;55(2 Suppl):594S-596S.

10. Sugerman HJ, Fairman RP, Sood RK, et al. Long-term effects of gastric surgery for treating respiratory insufficiency of obesity. Am J Clin Nutr 1992;55(2 Suppl):597S-601S.

11. Pillar G, Peled R, Lavie P. Recurrence of sleep apnea without concomitant weight increase 7.5 years after weight reduction surgery. Chest 1994;106:1702-4.

12. Scheuller M, Weider D. Bariatric surgery for treatment of sleep apnea syndrome in 15 morbidly obese patients: Long-term results. Otolaryngol Head Neck Surg 2001;125:299-302.

13. Guardiano SA, Scott JA, Ware JC, Schechner SA. The long-term results of gastric bypass on indexes of sleep apnea. Chest 2003;124:1615-9.

14. Rasheid S, Banasiak M, Gallagher SF, et al. Gastric bypass is an effective treatment for obstructive sleep apnea in patients with clinically significant obesity. Obes Surg 2003;13:58-61.

15. Valencia-Flores M, Orea A, Herrera M, et al. Effect of bariatric surgery on obstructive sleep apnea and hypopnea syndrome, electrocardiogram, and pulmonary arterial pressure. Obes Surg 2004;14:755-62.

16. Dixon JB, Schachter LM, O'Brien PE. Polysomnography before and after weight loss in obese patients with severe sleep apnea. Int J Obes 2005;29:1048-54.

17. Kalra M, Inge T, Garcia V, et al. Obstructive sleep apnea in extremely overweight adolescents undergoing bariatric surgery. Obes Res 2005;13:1175-9.

18. Haines KL, Nelson LG, Gonzalez R, et al. Objective evidence that bariatric surgery improves obesity-related obstructive sleep apnea. Surgery 2007;141:354-8.

19. Fritscher LG, Canani S, Mottin CC, et al. Bariatric surgery in the treatment of obstructive sleep apnea in morbidly obese patients. Respiration 2007;74:647-52.

20. Lettieri CJ, Eliasson AH, Greenburg L. Persistence of obstructive sleep apnea after surgical weight loss. J Clin Sleep Med 2008;4:333-8

21. Rao A, Tey BH, Ramalingam G, Poh A. Obstructive sleep apnoea (OSA) patterns in bariatric surgical practice and response of OSA to weight loss after laparoscopic adjustable gastric banding (LAGB). Ann Acad Med Singapore 2009;38:587-93.

22. Sjöström L, Narbro K, Sjöström CD, et al. Effects of bariatric surgery on mortality in Swedish obese subjects. N Engl J Med 2007;357:741-52.

23. Adams TD, Gress RE, Smith SC, et al. Long-term mortality after gastric bypass surgery. N Engl J Med 2007;357:753-61.

24. Perry CD, Hutter MM, Smith DB, Newhouse JP, McNeil BJ. Survival and changes in comorbidities after bariatric surgery. Ann Surg 2008;247:21-7.

25. LABS writing group. Perioperative safety in the longitudinal assessment of bariatric surgery. N Engl J Med 2009;361:445-54.

26. Padwal RS, Rucker D, Li SK, Curioni C, Lau DCW. Long-term pharmacotherapy for obesity and overweight. Cochrane Database Syst Rev 2003;(4):CD004094.

\section{SECTION VI: TREATMENT OF CSAS IN HF PATIENTS}

Question

Does treatment of CSAS in patients with HF lead to improved outcomes compared with standard medical therapy for HF?

\section{Introduction}

The indications to treat CSAS, often referred to as Cheyne-Stokes respiration (CSR), in patients with HF are not clear. Studies $(1,2)$ report that such patients are usually not hypersomnolent. Thus, it remains unclear whether subjective daytime sleepiness is an indication to treat and, if so, whether improvement in this symptom is clinically significant. It is also unclear what the optimum therapy should be for such an indication. Therefore, there is insufficient evidence to recommend therapy for CSAS in HF patients with daytime sleepiness. Another possible indication to treat is to improve survival and reduce the need for cardiac transplantation. One study (3) demonstrated a dose-response relationship between the AHI and risk of cardiac death (ie, death due to cardiac causes or heart transplantation), with worse transplant-free survival in patients with an AHI of 30 or greater than in those with an AHI of less than 30. In another study (4), it was shown that the best cutoff to predict mortality risk was an AHI of greater than 15. Considering the nonrandomized trial evidence that intensification of pharmacological therapy and cardiac resynchronization therapy for HF can attenuate CSAS $(5,6)$, medical therapy for HF should be optimized according to current recommendations of national cardiovascular associations such as the Canadian Cardiovascular Society (7), the American Heart Association and the American College of Cardiology (8). The only evidence of a survival benefit in treating CSAS in HF patients comes from the post hoc analysis of the Canadian Continuous Positive Airway Pressure for Patients with Central Sleep Apnea and Heart Failure (CANPAP) trial (9). Based on this study, consideration should be given to a trial of CPAP starting at a low level of $5 \mathrm{cmH}_{2} \mathrm{O}$, and increasing to a level that reduces the $\mathrm{AHI}$ to less than 15 or to the highest level tolerated over a period of days to weeks. PSG should be repeated within one to three months of CPAP initiation to assess its effect on the AHI. If the AHI at this time has decreased to less than 15, CPAP could be continued with close follow-up because it may lead to improved transplant-free survival. If, on the other hand, the AHI remains greater than 15, CPAP should be discontinued because its continued use may be associated with a poorer prognosis.

\section{Results}

Literature search: The literature search included various types of RCTs and non-RCTs, with a control group involving patients with HF and CSAS in which a number of interventions were assessed including oxygen $\left(\mathrm{O}_{2}\right)$, CPAP and adaptive servoventilation (ASV). Outcomes assessed included mortality, heart transplantation, morbidity, hospitalizations, LVEF, sympathetic nervous system activity, QoL and AHI. Table VI-1 summarizes the results of 11 such trials that were of at least four weeks duration.

\section{CSAS and HF}

Pathophysiology: In HF patients, CSAS is associated with chronic hypocapnia related to elevated left ventricular filling pressures and end-diastolic volumes, pulmonary congestion that may provoke hyperventilation through stimulation of pulmonary vagal irritant receptors, and to increases in central and peripheral chemosensitivity (10-13). Central apneas are triggered by hyperventilation and consequent reductions in the partial pressure of carbon dioxide $\left(\mathrm{PCO}_{2}\right)$ below the apneic threshold, often provoked by arousals (14). Similar to OSAS, CSAS causes intermittent nocturnal hypoxia, and surges in sympathetic nervous system activity and blood pressure (15). In contrast to OSAS, however, CSAS does not cause generation of negative intrathoracic pressure (14). Sympathetic nervous activity is also higher during sleep and 
TABLE VI-1

Literature search results - controlled clinical trials

\begin{tabular}{|c|c|c|c|c|c|}
\hline \multirow{2}{*}{$\begin{array}{l}\text { Author } \\
\text { (reference), year }\end{array}$} & \multirow[b]{2}{*}{ Study type } & \multirow[b]{2}{*}{ Patients, n } & \multicolumn{3}{|c|}{ Outcomes } \\
\hline & & & 1 & 2 & 3 \\
\hline $\begin{array}{l}\text { Naughton et al (59), } \\
1995\end{array}$ & $\begin{array}{l}\text { RCT assessing effect of CPAP on } \\
\text { AHI, LVEF and QoL over } 3 \text { months }\end{array}$ & 24 & CPAP reduced $\mathrm{AHI}$ by $66 \%$ & $\begin{array}{l}\text { CPAP increased LVEF by } \\
8 \%\end{array}$ & $\begin{array}{l}\text { CPAP reduced fatigue and } \\
\text { improved disease } \\
\text { mastery }\end{array}$ \\
\hline $\begin{array}{l}\text { Naughton et al (17), } \\
1995\end{array}$ & $\begin{array}{l}\text { RCT assessing effect of CPAP on } \\
\text { sympathetic activity over } 3 \text { months }\end{array}$ & 17 & $\begin{array}{l}\text { CPAP reduced nocturnal } \\
\text { urinary and daytime plasma } \\
\text { NA }\end{array}$ & & \\
\hline $\begin{array}{l}\text { Tkacova et al (60), } \\
1997\end{array}$ & $\begin{array}{l}\text { RCT assessing effect of CPAP on } \\
\text { mitral regurgitation over } 3 \text { months }\end{array}$ & 17 & $\begin{array}{l}\text { CPAP reduced mitral } \\
\text { regurgitant fraction by } 42 \%\end{array}$ & $\begin{array}{l}\text { CPAP reduced plasma } \\
\text { atrial natriuretic peptide } \\
\text { level by } 47 \mathrm{pg} / \mathrm{mL}\end{array}$ & \\
\hline Sin et al (19), 2000 & $\begin{array}{l}\text { 3-month RCT followed by 2.2-year } \\
\text { mean follow-up assessing effect of } \\
\text { CPAP on heart transplant-free } \\
\text { survival }\end{array}$ & $\begin{array}{c}66 \text { (29 with } \\
\text { CSA and } 37 \\
\text { without sleep } \\
\text { apnea) }\end{array}$ & $\begin{array}{l}\text { CPAP associated with trend } \\
\text { to better heart transplant- } \\
\text { free survival in CSA group } \\
(P=0.059) \text {, but not in the } \\
\text { non-CSA group }\end{array}$ & $\begin{array}{l}\text { CPAP increased LVEF in } \\
\text { CSA group, but not in } \\
\text { nonsleep-apnea group }\end{array}$ & \\
\hline $\begin{array}{l}\text { Bradley et al (57), } \\
2005\end{array}$ & $\begin{array}{l}\text { CANPAP trial: RCT for mean } \\
2 \text { years assessing effects of CPAP } \\
\text { on heart transplant-free survival }\end{array}$ & 258 & $\begin{array}{l}\text { CPAP had no effect on heart } \\
\text { transplant-free survival }\end{array}$ & $\begin{array}{l}\text { CPAP had no effect on } \\
\text { hospitalization rate or } \\
\text { QoL }\end{array}$ & $\begin{array}{l}\text { CPAP reduced AHI } \\
\text { (by 53\%) and plasma } \\
\text { NA level, and increased } \\
\text { LVEF and 6MWT } \\
\text { distance }\end{array}$ \\
\hline Arzt et al (9), 2007 & $\begin{array}{l}\text { Post hoc analysis of RCT (CANPAP) } \\
\text { to assess whether suppression of } \\
\text { CSA by CPAP improved heart } \\
\text { transplant-free survival }\end{array}$ & 220 & $\begin{array}{l}\text { In subgroup in whom CPAP } \\
\text { reduced } \mathrm{AHI} \text { to }<15 \text {, heart } \\
\text { transplant-free survival was } \\
\text { greater than in the control } \\
\text { group: } \mathrm{HR}=0.371, \mathrm{P}=0.043\end{array}$ & & \\
\hline Arzt et al (43), 2005 & $\begin{array}{l}\text { Non-RCT assessing the effects of } \\
\text { CPAP vs } \mathrm{O}_{2} \text { over } 12 \text { weeks }\end{array}$ & 26 & $\begin{array}{l}\text { CPAP increased ventilatory } \\
\text { efficiency during maximum } \\
\text { exercise, but } \mathrm{O}_{2} \text { did not }\end{array}$ & $\begin{array}{l}\text { CPAP increased LVEF, } \\
\text { but } \mathrm{O}_{2} \text { did not }\end{array}$ & $\begin{array}{l}\text { Both } \mathrm{CPAP} \text { and } \mathrm{O}_{2} \\
\text { reduced } \mathrm{AHI} \text { by } 67 \%\end{array}$ \\
\hline $\begin{array}{l}\text { Staniforth et al (42), } \\
1998\end{array}$ & $\begin{array}{l}\text { Double crossover RCT to assess } \\
\text { effects of } \mathrm{O}_{2} \text { on CSA over } 4 \text { weeks }\end{array}$ & 11 & $\mathrm{O}_{2}$ reduced $\mathrm{AHI}$ by $34 \%$ & $\begin{array}{l}\mathrm{O}_{2} \text { reduced nocturnal } \\
\text { urinary NA by } 50 \%\end{array}$ & $\begin{array}{l}\mathrm{O}_{2} \text { had no effects of } \mathrm{QoL} \\
\text { neurocognitive function } \\
\text { or alertness }\end{array}$ \\
\hline $\begin{array}{l}\text { Sasayama et al } \\
\text { (44), } 2009\end{array}$ & $\begin{array}{l}\text { RCT assessing effect of nocturnal } \\
\text { home } \mathrm{O}_{2} \text { on cardiovascular event } \\
\text { rates, LVEF and subjective } \\
\text { exercise capacity in heart faiure } \\
\text { patients with CSA over } 1 \text { year }\end{array}$ & 51 & $\begin{array}{l}\mathrm{O}_{2} \text { had no effect on } \\
\text { cardiovascular event rate }\end{array}$ & $\begin{array}{l}\mathrm{O}_{2} \text { had no effect on LVEF } \\
\text { but improved subjective } \\
\text { exercise capacity }\end{array}$ & $\begin{array}{l}\mathrm{O}_{2} \text { reduced the } \mathrm{AHI} \text { by } \\
53 \%\end{array}$ \\
\hline $\begin{array}{l}\text { Pepperell et al (67), } \\
2003\end{array}$ & $\begin{array}{l}\text { RCT assessing effect of ASV on } \\
\text { alertness over } 4 \text { weeks }\end{array}$ & 30 & $\begin{array}{l}\text { ASV increased alertness } \\
\text { (Osler test) }\end{array}$ & $\begin{array}{l}\text { ASV reduced AHI from } \\
25 \text { to } 5\end{array}$ & $\begin{array}{l}\text { ASV reduced BNP and } \\
\text { nocturnal urinary } \\
\text { metadrenaline, but no } \\
\text { effect on QoL or driving } \\
\text { simulator performance }\end{array}$ \\
\hline $\begin{array}{l}\text { Philippe et al (64), } \\
2006\end{array}$ & $\begin{array}{l}\text { RCT comparing effects of ASV and } \\
\text { CPAP on AHI, LVEF and QOL over } \\
6 \text { months }\end{array}$ & 17 & $\begin{array}{l}\text { ASV caused a greater } \\
\text { reduction in } \mathrm{AHI} \text { than CPAP }\end{array}$ & $\begin{array}{l}\text { Effects on LVEF uncertain } \\
\text { because of small } \\
\text { number who had it } \\
\text { assessed }\end{array}$ & $\begin{array}{l}\text { QoL improved more with } \\
\text { ASV than CPAP }\end{array}$ \\
\hline $\begin{array}{l}\text { Kasai et al (66), } \\
2010\end{array}$ & $\begin{array}{l}\text { RCT of ASV vs CPAP assessing } \\
\text { effects on CSA and cardiac } \\
\text { function over } 3 \text { months }\end{array}$ & 31 & $\begin{array}{l}\text { ASV compliance was better } \\
\text { than CPAP }(5.2 \text { vs } 4.4 \mathrm{~h} / \text { day, } \\
\mathrm{P}<0.05) \text { and ASV reduced } \\
\text { AHI more than CPAP } \\
(-32 \text { vs }-24 ; \mathrm{P}<0.05)\end{array}$ & $\begin{array}{l}\text { ASV increased LVEF by } \\
7 \% \text { more than CPAP } \\
(P<0.05) \text { and increased } \\
6 \mathrm{MWT} \text { distance and QoL } \\
\text { more than CPAP }\end{array}$ & $\begin{array}{l}\text { ASV reduced BNP and NA } \\
\text { levels more than CPAP }\end{array}$ \\
\hline
\end{tabular}

6MWT 6 min walk test; AHI Apnea/hypopnea index; ASV Adaptive servoventilation; BNP Brain natriuretic peptide; CANPAP Canadian Continuous Positive Airway Pressure for Patients with Central Sleep Apnea and Heart Failure trial; CPAP Continuous positive airway pressure; CSA Central sleep apnea; LVEF Left ventricular ejection fraction; NA Noradrenaline; $\mathrm{O}_{2}$ Oxygen; QoL Quality of life; RCT Randomized controlled trial; vs Versus

wakefulness in HF patients with CSAS than in individuals without sleep apnea $(16,17)$.

Impact on clinical outcome: Because CSAS is seldom associated with excessive daytime sleepiness $(1,18)$, its main clinical significance in patients with HF lies in its potential to increase the risk of death and cardiac transplantation independently of known risk factors. However, this point remains controversial, with some studies supporting this adverse relationship (3,4,19-22) and others not (23,24). Nevertheless, the balance of the evidence favours an adverse effect of CSAS on prognosis in HF. In a recent study (4), receiver operating characteristic curve analysis demonstrated that an AHI of greater than 15 was the best predictor of increased mortality risk in HF patients with either OSA or CSAS. This suggests a target AHI above which therapy of the breathing disorder has the potential to improve survival, although this possibility remains to be tested. One mechanism through which CSAS likely contributes to reduced survival is increased sympathetic nervous system activity due to the combined effects of apnea, intermittent hypoxia, fluctuations in $\mathrm{PCO}_{2}$ and arousals from sleep $(3,17,25)$. 


\section{Treatment of CSAS in HF}

Treatment of HF: Because CSAS is largely a consequence of HF, firstline therapy should be optimization of HF treatment. However, there are no RCTs that support this approach. Nevertheless, case series $(5,26)$ suggest that intensification of pharmacological therapy for HF can attenuate CSAS. Similarly, in non-RCTs $(6,27)$, cardiac resynchronization pacemaker therapy was accompanied by alleviation of CSAS and associated with an improvement in cardiac function. Heart transplantation has also been associated with alleviation of CSAS in HF patients (28). Mechanisms through which treatment of HF might attenuate CSAS have not been identified, but probably involve lowering of LV filling pressure, reduction in pulmonary congestion and increasing cardiac output, with a subsequent reduction in pulmonary vagal afferent irritant receptor stimulation and increase in $\mathrm{PCO}_{2}(10,11,29)$.

\section{Specific treatment of CSAS in HF patients}

Respiratory stimulants: Theophylline stimulates central respiratory drive and augments cardiac contractility by antagonism of adenosine. In an RCT involving 15 patients with stable HF and CSAS (30), theophylline administered for five days reduced the AHI, but did not improve LVEF. However, theophylline - once widely used for therapy of acute $\mathrm{HF}$ - is no longer used for this purpose because it increases the incidence of cardiac arrhythmias (31) and sudden death (32). Therefore, until larger longer-term trials are performed to demonstrate its safety and efficacy, theophylline cannot be recommended for therapy of CSAS in patients with HF. The carbonic anhydrase inhibitor acetazolamide stimulates respiration by causing metabolic acidosis. In a short-term RCT of $12 \mathrm{HF}$ patients with CSAS (33), acetazolamide reduced the AHI by $38 \%$, and decreased daytime sleepiness and fatigue. However, it cannot be recommended for therapy of CSAS in HF at this time because its long-term safety and effectiveness in such patients remain to be demonstrated.

Atrial overdrive pacing: In an RCT involving patients with bradyarrhythmias without HF, Garrigue et al (34) observed that atrial pacing of the heart at 15 beats/min above its intrinsic rate during sleep caused a $50 \%$ reduction in both central and obstructive apneas and hypopneas. The most likely mechanism for alleviation of CSAS was by augmentation of cardiac output and relief of pulmonary congestion. However, it was not clear how atrial pacing alleviated obstructive events. In three subsequent RCTs (35-37), atrial overdrive pacing had no significant effect on AHI in OSAS patients without HF. Moreover, long-term overdrive pacing in HF patients who have no established indication for a pacemaker may cause harm by promoting pacing-induced arrhythmias (38). Consequently, the evidence does not support atrial overdrive pacing as a treatment for either CSAS or OSAS in the absence of another indication for its use.

$\mathrm{O}_{2}$ : Small RCTs of one night to one month in duration have demonstrated that nocturnal $\mathrm{O}_{2}$ reduces the AHI by approximately $50 \%$ in HF patients with CSAS (39-41). Staniforth et al (42) additionally found that supplemental $\mathrm{O}_{2}$ for one month reduced overnight urinary noradrenaline excretion, but had no effect on daytime plasma noradrenaline and brain natriuretic peptide levels, neurocognitive function, sleepiness or QoL. In another RCT, Andreas et al (39) reported that administration of nocturnal $\mathrm{O}_{2}$ to $22 \mathrm{HF}$ patients for seven days improved peak $\mathrm{O}_{2}$ consumption and ventilatory efficiency, but had no effect on QoL. Arzt et al (43) allocated 10 consecutive patients to nocturnal $\mathrm{O}_{2}$ and the next 16 consecutive patients to CPAP at $8 \mathrm{cmH}_{2} \mathrm{O}$ to $10 \mathrm{cmH}_{2} \mathrm{O}$ for three months. Both CPAP and $\mathrm{O}_{2}$ reduced the AHI by $67 \%$, but only CPAP improved ventilatory efficiency and LVEF. Neither intervention had any effect on peak exercise $\mathrm{O}_{2}$ consumption. In a one-year RCT involving $51 \mathrm{HF}$ patients with CSAS, Sasayama et al (44) demonstrated that nocturnal $\mathrm{O}_{2}$ reduced the AHI by $53 \%$ and was associated with an improvement in subjective exercise capacity, but had no effect on cardiovascular events or LVEF.

Although $\mathrm{O}_{2}$ attenuates CSAS in HF patients and can reduce nocturnal sympathetic nervous activity, there is no consistent evidence that it improves cardiovascular function or clinical outcomes in such patients. Consequently, the evidence does not support its use for therapy of CSAS in patients with HF. Moreover, administration of supplemental
$\mathrm{O}_{2}$ to $\mathrm{HF}$ patients may cause hyperoxia and, by doing so, increase the generation of oxygen free radicals and, hence, induce oxidative stress. This can exert adverse hemodynamic effects such as raising vascular resistance, blood pressure and LV filling pressure, and lowering cardiac output $(45,46)$. Therefore, larger trials are required to determine whether $\mathrm{O}_{2}$ improves clinical outcomes in HF patients with CSAS.

$\mathrm{CO}_{2}$ : Raising $\mathrm{PCO}_{2}$ above the apnea threshold, either via inhaled $\mathrm{CO}_{2}$ or addition of dead space, abolishes CSAS instantaneously in HF patients $(47,48)$. However, there is no evidence that raising $\mathrm{PCO}_{2}$ improves cardiovascular outcomes in such patients. Moreover, raising $\mathrm{PCO}_{2}$ may cause adverse effects by activating the sympathetic nervous system (49). Therefore, raising $\mathrm{PCO}_{2}$ - either by inhalation of $\mathrm{CO}_{2}$ or by using a face mask with increased dead space - cannot be recommended for therapy of CSAS in HF patients at this time.

CPAP: CPAP reduces LV transmural pressure and afterload in patients with $\mathrm{HF}$ by increasing intrathoracic pressure (50). It also reduces LV preload by impeding venous return and reducing end-diastolic volume and pressure $(10,51)$. The acute response of cardiac output to CPAP therapy in awake HF patients is dependent on cardiac preload and rhythm. In HF patients with high LV filling pressures (ie, $12 \mathrm{mmHg}$ or greater), CPAP of $5 \mathrm{cmH}_{2} \mathrm{O}$ to $10 \mathrm{cmH}_{2} \mathrm{O}$ generally augments cardiac output; however, in HF patients with low LV filling pressures (ie, less than $12 \mathrm{mmHg})(52,53)$ or atrial fibrillation (54), it generally reduces cardiac output. It is not known whether CPAP has long-term adverse hemodynamic effects when applied nightly to HF patients with CSAS and low LV filling pressures or atrial fibrillation. Because CSAS in HF patients is associated with increased LV filling pressures (1), CPAP has been applied partly in an attempt to augment cardiac output $(53,54)$ and reduce LV filling pressure in addition to alleviating CSAS (10).

The effects of CPAP on CSAS in HF patients have been inconsistent, probably owing to differences in how it is applied. CSAS was not alleviated in RCTs $(55,56)$ in which nocturnal CPAP was applied for one night to two weeks at low pressure $\left(5 \mathrm{cmH}_{2} \mathrm{O}\right.$ to $\left.7.5 \mathrm{cmH}_{2} \mathrm{O}\right)$. In contrast, in settings in which patients were acclimatized to CPAP during a gradual two- to seven-day titration to higher pressures of $8 \mathrm{cmH}_{2} \mathrm{O}$ to $12.5 \mathrm{cmH}_{2} \mathrm{O}$, the frequency of central apneas and hypopneas fell by $50 \%$ to $67 \%$ after two to 12 weeks $(16,40,42,57-60)$.

In small, single-centre trials of one to three months duration in which CPAP was titrated gradually over days to weeks, CSAS was alleviated and associated with an increase in $\operatorname{LVEF}(2,43,59,61)$, reductions in mitral regurgitation (53) and in nocturnal and daytime noradrenaline levels (17). These physiological improvements were associated with significant improvements in HF symptoms (17). In one trial of CPAP in HF involving 29 patients with and 37 without CSAS (AHI of 15 or greater and less than 15, respectively) (11), CPAP had no effect on LVEF or the combined rate of mortality and cardiac transplantation among those without sleep apnea. In contrast, among patients with CSAS, CPAP improved LVEF after three months and was associated with a trend toward a reduced combined rate of mortality plus cardiac transplantation during the median 2.2-year follow-up period $(\mathrm{P}=0.059)$. Among patients who were adherent to CPAP, the reduction in the combined rate of death and cardiac transplantation was significant $(\mathrm{P}=0.017)$. Taken together, these findings imply that CPAP improves cardiovascular function over time in HF patients with CSAS by attenuating the adverse cardiovascular effects of CSAS.

The multicentre CANPAP trial (57) sought to determine whether CPAP improved CSAS, morbidity, mortality and cardiovascular function in HF patients with CSAS on optimal contemporary HF therapy. The trial enrolled 258 patients with HF (LVEF lower than 40\%) and CSAS (AHI of $15 / \mathrm{h}$ of sleep or greater of which more than $50 \%$ of apneas and hypopneas were central): 130 were randomly assigned to a control group and 128 to a CPAP-treated group. The intention-totreat analyses demonstrated that CPAP reduced the AHI by $53 \%$, improved mean and minimum nocturnal oxygenation by $2 \%$ and $5 \%$, respectively, and LVEF by $2.2 \%$ and lowered plasma noradrenaline concentration by $1.03 \pm 1.84 \mathrm{nmol} / \mathrm{L}$ over a period of at least two years. In addition, CPAP therapy led to a significant $20 \mathrm{~m}$ increase in $6 \mathrm{~min}$ 
walk test distance. However, CPAP did not reduce transplant-free survival ( 32 versus 32 events; $\mathrm{P}=0.54$ ), rate of hospitalizations or $\mathrm{QoL}$ compared with the control group. Survival analysis revealed a divergence of event rates in the first 18 months favouring the control group $(\mathrm{P}=0.02)$ that crossed over after 18 months to favour CPAP $(\mathrm{P}=0.06)$. This suggested that there were two subgroups - one that responded to CPAP and one that did not.

In a post hoc analysis of CANPAP, Arzt et al (9) found no baseline characteristic of the study population that predicted a beneficial response. However, they observed that three months after randomization, if CPAP suppressed the AHI to below the entry criterion of 15, transplant-free survival was significantly greater than in both the control group and the CPAP-treated group in whom the AHI remained above 15. In contrast, when CPAP failed to reduce the AHI to below 15 , its use was not associated with any improvement in heart transplantfree survival. These data suggested that early suppression of CSAS by CPAP in HF patients was a key therapeutic target to improve survival. Collectively, these data indicated that although the CANPAP trial lacked the power to conclude with certainty that CPAP does not improve survival in this patient population, the authors do not support its routine use to prolong survival in patients with CSAS and HF. However, the post hoc analysis suggested that because an early reduction in the AHI was accompanied by improvement in transplant-free survival, it is reasonable to provide a trial of CPAP to such patients with close follow-up.

Other forms of PAP: Two other types of noninvasive PAP have been evaluated in HF patients: bilevel pressure support (BPAP) in the spontaneous-timed mode with a back-up rate, and ASV. The latter provides $4 \mathrm{cmH}_{2} \mathrm{O}$ to $5 \mathrm{cmH}_{2} \mathrm{O}$ expiratory, and $8 \mathrm{cmH}_{2} \mathrm{O}$ to $10 \mathrm{cmH}_{2} \mathrm{O}$ end-inspiratory pressure support during regular breathing. When a central apnea is detected, inspiratory pressure support increases up to $15 \mathrm{cmH}_{2} \mathrm{O}$ to maintain minute ventilation at $80 \%$ to $90 \%$ of the longterm average ventilation. In both cases, central apneas are overridden when inspiratory pressure support is triggered by the cessation of airflow. When the device detects that patients are making breathing efforts, inspiratory support is withdrawn.

Only a few studies have compared different interventions for therapy of CSAS in HF. Teschler et al (62) compared the effects of a single night each of supplemental $\mathrm{O}_{2}(2 \mathrm{~L} / \mathrm{min})$, CPAP (mean $9.3 \mathrm{cmH}_{2} \mathrm{O}$ ), BPAP (mean $13.5 \mathrm{cmH}_{2} \mathrm{O} / 5.2 \mathrm{cmH}_{2} \mathrm{O}$ ) and ASV (mean $7 \mathrm{cmH}_{2} \mathrm{O}$ to $9 \mathrm{cmH}_{2} \mathrm{O}$ ) on CSAS and sleep quality on five consecutive nights in random order in $14 \mathrm{HF}$ patients. The AHI declined significantly from 36 (control) to $18\left(\mathrm{O}_{2}\right)$, to 15 (CPAP), to 6 (BPAP) and to 4 (ASV). However, effects on cardiovascular function were not assessed. Arzt et al (63) examined the effects of ASV titrated over two nights in $14 \mathrm{HF}$ patients with CSAS in whom chronic CPAP or BPAP therapy had failed to reduce the AHI to below 10. In all cases, ASV was able to reduce the AHI to less than 10, and to a lower level than with either CPAP or BPAP. These data indicated that in CPAP- or BPAP-resistant CSAS, ASV was more effective than both in suppressing CSAS. However, effects of ASV on cardiovascular function were not tested. Köhnlein et al (58) found that BPAP and CPAP caused similarly significant reductions in AHI in $16 \mathrm{HF}$ patients with CSAS over two weeks, but did not assess cardiac function. In a six-month RCT of ASV versus CPAP, Philippe et al (64) found that ASV caused a greater reduction in the AHI than CPAP in association with a greater improvement in HF-related QoL, but no effect on daytime sleepiness. However, CPAP was not titrated and the pressure was lower than the effective pressure used in previous studies (59-61,65), thus making comparisons between the two interventions difficult. Because LVEF was measured at followup in only 13 patients, no conclusions about effects on cardiovascular function could be drawn. Kasai et al (66) compared the effects of ASV versus CPAP in 31 patients with HF and CSAS in a three-month RCT. They found that the ASV group had better compliance, greater reductions in AHI, plasma brain natriuretic peptide and noradrenaline levels, and a greater increase in LVEF and QoL than the CPAP group.
Pepperell et al (67) performed a one-month RCT of therapeutic versus subtherapeutic ASV in 30 stable HF patients with CSAS. The primary outcome measure was the assessment of alertness using the Osler maintenance of wakefulness test. They reported that ASV improved alertness but not sleepiness according to the ESS score. ASV did not lead to any improvement according to general or disease-specific health status questionnaires, or in performance on a driving simulator. Nocturnal urinary metadrenaline and daytime brain natriuretic peptide concentrations were reduced by therapeutic ASV. However, because follow-up PSG was not performed at the end of the trial, the effects of these interventions on AHI and sleep quality were not determined.

The available evidence indicates that it is premature to recommend forms of variable positive pressure support for therapy of CSAS in HF patients because these interventions have not consistently been shown to improve cardiac function, QoL, morbidity or mortality, nor have they been subjected to large-scale, long-term RCTs. However, among HF patients with CSAS, CPAP has only been shown to improve cardiovascular function after central sleep apnea has been alleviated (19). Because other forms of PAP such as ASV generally cause greater suppression of CSAS than CPAP $(62,64)$, it may, therefore, be reasonable to subject them to large-scale RCTs to assess whether they have a beneficial effect on cardiovascular end points.

\section{Conclusions}

In patients with HF, CSAS is seldom accompanied by a complaint of hypersomnolence $(10,11)$, and there is no consistent evidence that treating CSAS with $\mathrm{O}_{2}$ or various forms of PAP relieves this symptom $(39,42,66)$. Therefore, indications to treat are unclear. Because CSAS is associated with increased mortality risk in patients with HF, the main reason to treat CSAS would be to improve cardiovascular function, and to reduce morbidity and mortality from HF. Because CSAS appears to arise secondary to HF in many patients, optimization of medical HF therapy should be the first step in its management because this may attenuate it (5). While the CANPAP trial demonstrated that CPAP attenuates CSAS and improves cardiovascular function in patients with HF (57), it did not demonstrate any beneficial effects of CPAP on morbidity and mortality. Therefore, the data do not support its routine use in patients with CSAS and HF to prolong life. However, a post hoc analysis of the CANPAP trial revealed that when CPAP reduced the AHI to less than 15 , heart transplant-free survival improved compared with the control group (9).

Chronic CPAP therapy appears to improve cardiovascular function in HF patients with CSAS when it relieves CSAS $(19,56)$. These observations suggest that alleviation of CSA is a key factor in improving cardiac function in HF patients with CSAS. Therefore, interventions (eg, ASV) that reduce AHI to a greater extent than CPAP may provide greater benefits in the long-term than CPAP. Until such trials are conducted, however, the evidence does not support widespread screening for CSAS in HF patients without symptoms of sleep apnea.

\footnotetext{
Question \#6

Does treatment of CSAS in HF patients lead to improved outcomes compared with the standard medical therapy for HF?

\section{Recommendations}

The following recommendations are based on limited evidence from non-RCTs, RCTs and the consensus of the sleep apnea expert panel:

1. Optimization of medical HF therapy should be the first step in the management of CSAS in patients with HF. (Grade of recommendation: $1 \mathrm{C}$ )

2. If CSAS persists after optimal medical HF treatment has been established, patients should be considered for a three-month trial of CPAP. If the AHI has decreased to below 15 on a repeat sleep study, CPAP can be continued. However, if the AHI remains at 15 or greater, CPAP should be discontinued. (Grade of recommendation: $2 \mathrm{C}$ )
} 


\section{REFERENCES}

1. Javaheri S, Parker TJ, Liming JD, et al. Sleep apnea in 81 ambulatory male patients with stable heart failure. Types and their prevalences, consequences, and presentations. Circulation 1998;97:2154-9.

2. Yumino D, Wang H, Floras JS, et al. Prevalence and physiological predictors of sleep apnea in heart failure. J Cardiac Fail 2009; $15: 279-85$.

3. Lanfranchi PA, Braghiroli A, Bosimini E, et al. Prognostic value of nocturnal Cheyne-Stokes respiration in chronic heart failure. Circulation 1999;99:1435-40.

4. Yumino D, Wang H, Floras JS, et al. Increased mortality risk in patients with sleep apnea and ischemic heart failure. Heart 2009;95:819-24.

5. Walsh JT, Andrews R, Starling R, Cowley AJ, Johnston ID, Kinnear WJ. Effects of captopril and oxygen on sleep apnoea in patients with mild to moderate congestive cardiac failure. Br Heart J 1995;73:237-41.

6. Sinha AM, Skobel EC, Breithardt OA, et al. Cardiac resynchronization therapy improves central sleep apnea and Cheyne-Stokes respiration in patients with chronic heart failure. J Am Coll Cardiol 2004;44:68-71.

7. Arnold JM, Liu P, Demers C, et al; Canadian Cardiovascular Society. Canadian Cardiovascular Society consensus conference recommendations on heart failure 2006: Diagnosis and management. Can J Cardiol 2006;22:23-45.

8. Hunt SA, Abraham WT, Chin MH, et al; American College of Cardiology; American Heart Association Task Force on Practice Guidelines; American College of Chest Physicians; International Society for Heart and Lung Transplantation; Heart Rhythm Society. ACC/AHA 2005 Guideline Update for the Diagnosis and Management of Chronic Heart Failure in the Adult: A report of the American College of Cardiology/American Heart Association Task Force on Practice Guidelines (Writing Committee to Update the 2001 Guidelines for the Evaluation and Management of Heart Failure): Developed in collaboration with the American College of Chest Physicians and the International Society for Heart and Lung Transplantation: Endorsed by the Heart Rhythm Society. Circulation 2005;112:154-235.

9. Arzt M, Floras JS, Logan AG, et al; for the CANPAP Investigators. Suppression of central sleep apnea by continuous positive airway pressure and transplant-free survival in heart failure. Circulation 2007;115:3173-80.

10. Solin P, Bergin P, Richardson M, Kaye DM, Walters EH, Naughton MT. Influence of pulmonary capillary wedge pressure on central apnea in heart failure. Circulation 1999;99:1574-9.

11. Lorenzi-Filho G, Azevedo ER, Parker JD, Bradley TD. Relationship of carbon dioxide tension in arterial blood to pulmonary wedge pressure in heart failure. Eur Respir J 2002;19:37-40.

12. Tkacova R, Hall MJ, Liu PP, Fitzgerald FS, Bradley TD. Left ventricular volume in patients with heart failure and Cheyne-Stokes respiration during sleep. Am J Respir Crit Care Med 1997;156:1549-55.

13. Sin DD, Fitzgerald F, Parker JD, Newton G, Floras JS, Bradley TD. Risk factors for central and obstructive sleep apnea in 450 men and women with congestive heart failure. Am J Respir Crit Care Med 1999;160:1101-6.

14. Naughton M, Benard D, Tam A, Rutherford R, Bradley TD. Role of hyperventilation in the pathogenesis of central sleep apneas in patients with congestive heart failure. Am Rev Respir Dis 1993;148:330-8.

15. Leung RS, Floras JS, Lorenzi-Filho G, Rankin F, Picton P, Bradley TD. Influence of Cheyne-Stokes respiration on cardiovascular oscillations in heart failure. Am J Respir Crit Care Med 2003;167:1534-9.

16. Spaak J, Egri ZJ, Kubo T, et al. Muscle sympathetic nerve activity during wakefulness in heart failure patients with and without sleep apnea. Hypertension 2005;46:1327-32.

17. Naughton MT, Benard DC, Liu PP, Rutherford R, Rankin F, Bradley TD. Effects of nasal CPAP on sympathetic activity in patients with heart failure and central sleep apnea. Am J Respir Crit Care Med 1995;152:473-9.

18. Ferrier K, Campbell A, Yee B, et al. Sleep disordered breathing occurs frequently in stable outpatients with congestive heart failure. Chest 2005;128:2116-22.

19. Sin DD, Logan AG, Fitzgerald FS, Liu PP, Bradley TD. Effects of continuous positive airway pressure on cardiovascular outcomes in heart failure patients with and without Cheyne-Stokes respiration. Circulation 2000;102:61-6.
20. Corra U, Pistono M, Mezzani A, et al. Sleep and exertional periodic breathing in chronic heart failure: Prognostic importance and interdependence. Circulation 2006;113:44-50.

21. Javaheri S, Shukla R, Zeigler H, Wexler L. Central sleep apnea, right ventricular dysfunction, and low diastolic blood pressure are predictors of mortality in systolic heart failure. J Am Coll Cardiol 2007;49:2028-34.

22. Hanly PJ, Zuberi-Khokhar NS. Increased mortality associated with Cheyne-Stokes respiration in patients with congestive heart failure. Am J Respir Crit Care Med 1996;153:272-6.

23. Andreas S, Hagenah G, Moller C, Werner GS, Kreuzer H. Cheyne-Stokes respiration and prognosis in congestive heart failure. Am J Cardiol 1996;78:1260-4.

24. Roebuck T, Solin P, Kaye DM, Bergin P, Bailey M, Naughton MT. Increased long-term mortality in heart failure due to sleep apnoea is not yet proven. Eur Respir J 2004;23:735-40.

25. van de Borne P, Oren R, Abouassaly C, Anderson E, Somers VK. Effect of Cheyne-Stokes respiration on muscle sympathetic nerve activity in severe congestive heart failure secondary to ischemic or idiopathic dilated cardiomyopathy. Am J Cardiol 1998;81:432-6.

26. Dark DS, Pingleton SK, Kerby GR, et al. Breathing pattern abnormalities and arterial oxygen desaturation during sleep in the congestive heart failure syndrome. Improvement following medical therapy. Chest 1987;91:833-6.

27. Gabor JY, Newman DA, Barnard-Roberts V, et al. Improvement in Cheyne-Stokes respiration following cardiac resynchronisation therapy. Eur Respir J 2005;26:95-100.

28. Mansfield DR, Solin P, Roebuck T, Bergin P, Kaye DM, Naughton MT. The effect of successful heart transplant treatment of heart failure on central sleep apnea. Chest 2003;124:1675-81.

29. Naughton MT, Benard DC, Rutherford R, Bradley TD. Effect of continuous positive airway pressure on central sleep apnea and nocturnal $\mathrm{PCO}_{2}$ in heart failure. Am J Resp Crit Care Med 1994;150:1598-604.

30. Javaheri S, Parker TJ, Wexler L, Liming JD, Lindower P, Roselle GA. Effect of theophylline on sleep disordered breathing in heart failure. N Engl J Med 1996;335:562-7.

31. Bittar G, Friedman HS. The arrhythmogenicity of theophylline. A multivariate analysis of clinical determinants. Chest 1991;99:1415-20.

32. Suissa S, Hemmelgarn B, Blais L, Ernst P. Bronchodilators and acute cardiac death. Am J Respir Crit Care Med 1996;154:1598-602.

33. Javaheri S. Acetazolamide improves central sleep apnea in heart failure: A double-blind, prospective study. Am J Respir Crit Care Med 2006;173:234-7.

34. Garrigue S, Bordier P, Jais P, et al. Benefit of atrial pacing in sleep apnea syndrome. N Engl J Med 2002;346:404-12.

35. Luthje L, Unterberg-Buchwald C, Dajani D, Vollmann D, Hasenfuss G, Andreas S. Atrial overdrive pacing in patients with sleep apnea with implanted pacemaker. Am J Respir Crit Care Med 2005;172:118-22.

36. Pepin JL, Defaye P, Garrigue S, Poezevara Y, Levy P. Overdrive atrial pacing does not improve obstructive sleep apnoea syndrome. Eur Respir J 2005;25:343-7.

37. Unterberg C, Luthje L, Szych J, Vollmann D, Hasenfuss G, Andreas S. Atrial overdrive pacing compared to CPAP in patients with obstructive sleep apnoea syndrome. Eur Heart J 2005;26:2568-75.

38. Himmrich E, Przibille O, Zellerhoff C, et al. Proarrhythmic effect of pacemaker stimulation in patients with implanted cardioverter defibrillators. Circulation 2003;108:192-7.

39. Andreas S, Clemens C, Sandholzer H, Figulla HR, Kreuzer H. Improvement of exercise capacity with treatment of Cheyne-Stokes respiration in patients with congestive heart failure. J Am Coll Cardiol 1996;27:1486-90.

40. Hanly PJ, Millar TW, Steljes DG, Baert R, Frais MA, Kryger MH. The effect of oxygen on respiration and sleep in patients with congestive heart failure. Ann Intern Med 1989;111:777-82.

41. Krachman SL, D'Alonzo GE, Berger TJ, Eisen HJ. Comparison of oxygen therapy with nasal continuous positive airway pressure on Cheyne-Stokes respiration during sleep in congestive heart failure. Chest 1999;116:1550-7.

42. Staniforth AD, Kinnear WJ, Starling R, Hetmanski DJ, Cowley AJ. Effect of oxygen on sleep quality, cognitive function and sympathetic activity in patients with chronic heart failure and Cheyne-Stokes respiration. Eur Heart J 1998;19:922-8.

43. Arzt M, Schulz M, Wensel R, et al. Nocturnal continuous positive airway pressure improves ventilatory efficiency during exercise in patients with chronic heart failure. Chest 2005;127:794-802. 
44. Sasayama S, Izumi T, Matsuzaki M, et al; for The CHF-HOT Study Group. Improvement of quality of life with nocturnal oxygen therapy in heart failure patients with central sleep apnea. Circ J 2009; 73:1255-62.

45. Haque WA, Boehmer J, Clemson BS, Leuenberger UA, Silber DH, Sinoway LI. Hemodynamic effects of supplemental oxygen administration in congestive heart failure. J Am Coll Cardiol 1996;27:353-7.

46. Mak S, Azevedo ER, Liu PP, Newton GE. Effect of hyperoxia on left ventricular function and filling pressures in patients with and without congestive heart failure. Chest 2001;120:467-73.

47. Khayat RN, Xie A, Patel AK, Kaminski A, Skatrud JB. Cardiorespiratory effects of added dead space in patients with heart failure and central sleep apnea. Chest 2003;123:1551-60.

48. Lorenzi-Filho G, Rankin F, Bies I, Bradley TD. Effects of inhaled carbon dioxide and oxygen on Cheyne-Stokes respiration in patients with heart failure. Am J Respir Crit Care Med 1999;159:1490-8.

49. Andreas S, Weidel K, Hagenah G, Heindl S. Treatment of Cheyne-Stokes respiration with nasal oxygen and carbon dioxide. Eur Respir J 1998;12:414-9.

50. Naughton MT, Rahman MA, Hara K, Floras JS, Bradley TD. Effect of continuous positive airway pressure on intrathoracic and left ventricular transmural pressures in patients with congestive heart failure. Circulation 1995;91:1725-31.

51. Mehta S, Liu PP, Fitzgerald FS, Allidina YK, Bradley TD. Effects of continuous positive airway pressure on cardiac volumes in patients with ischemic and dilated cardiomyopathy. Am J Respir Crit Care Med 2000;161:128-34.

52. Bradley TD, Holloway RM, McLaughlin PR, Ross BL, Walters J, Liu PP. Cardiac output response to continuous positive airway pressure in congestive heart failure. Am Rev Respir Dis 1992;145:377-82.

53. De Hoyos A, Liu PP, Benard DC, Bradley TD. Haemodynamic effects of continuous positive airway pressure in humans with normal and impaired left ventricular function. Clin Sci (Lond) 1995;88:173-8.

54. Kiely JL, Deegan P, Buckley A, Shiels P, Maurer B, McNicholas WT. Efficacy of nasal continuous positive airway pressure therapy in chronic heart failure: Importance of underlying cardiac rhythm. Thorax 1998;53:957-62.

55. Buckle P, Millar T, Kryger M. The effect of short-term nasal CPAP on Cheyne-Stokes respiration in congestive heart failure. Chest 1992;102:31-5.

56. Davies RJ, Harrington KJ, Ormerod OJ, Stradling JR. Nasal continuous positive airway pressure in chronic heart failure with sleep disordered breathing. Am Rev Respir Dis 1993;147:630-4.

57. Bradley TD, Logan AG, Kimoff RJ, et al. Continuous positive airway pressure for central sleep apnea and heart failure. N Engl J Med 2005;353:2025-33.

58. Köhnlein T, Welte T, Tan LB, Elliott MW. Assisted ventilation for heart failure patients with Cheyne-Stokes respiration. Eur Respir J 2002;20:934-41.

59. Naughton MT, Liu PP, Bernard DC, Goldstein RS, Bradley TD. Treatment of congestive heart failure and Cheyne-Stokes respiration during sleep by continuous positive airway pressure. Am J Respir Crit Care Med 1995;151:92-7.

60. Tkacova R, Liu PP, Naughton MT, Bradley TD. Effect of continuous positive airway pressure on mitral regurgitant fraction and atrial natriuretic peptide in patients with heart failure. J Am Coll Cardiol 1997;30:739-45
61. Takasaki Y, Orr D, Popkin J, Rutherford R, Liu P, Bradley TD. Effect of nasal continuous positive airway pressure on sleep apnea in congestive heart failure. Am Rev Respir Dis 1989;140:1578-84.

62. Teschler H, Dohring J, Wang YM, Berthon-Jones M. Adaptive pressure support servo-ventilation: A novel treatment for Cheyne-Stokes respiration in heart failure. Am J Respir Crit Care Med 2001;164:614-9.

63. Arzt M, Wensel R, Montalvan S, et al. Effects of dynamic bilevel positive airway pressure support on central sleep apnea in men with heart failure. Chest 2008;134:61-6.

64. Philippe C, Stoica-Herman M, Drouot X, et al. Compliance with and effectiveness of adaptive servoventilation versus continuous positive airway pressure in the treatment of Cheyne-Stokes respiration in heart failure over a six month period. Heart 2006;92:337-42.

65. Granton JT, Naughton MT, Benard DC, Liu PP, Goldstein RS, Bradley TD. CPAP improves inspiratory muscle strength in patients with heart failure and central sleep apnea. Am J Respir Crit Care Med 1996;153:277-82.

66. Kasai T, Usui Y, Yoshioka T, et al; JASV Investigators. Effect of flow-triggered adaptive servo-ventilation compared with continuous positive airway pressure in patients with chronic heart failure with coexisting obstructive sleep apnea and Cheyne-Stokes respiration. Circ Heart Fail 2010;3:140-8.

67. Pepperell JC, Maskell NA, Jones DR, et al. A randomized controlled trial of adaptive ventilation for Cheyne-Stokes breathing in heart failure. Am J Respir Crit Care Med 2003;168:1109-14.

\section{SECTION VII: CompSA}

Question

Is CompSA a distinct clinical syndrome and, if so, what criteria should be used to make the diagnosis of CompSA?

\section{Introduction}

The term 'CompSA' has emerged in the literature in the past five years, opening debate as to whether it is a distinct entity and how it should be defined. CompSA has been reported to occur in $6 \%$ to $15 \%$ of CPAP-treated OSAS patients. Although there are reports of CompSA being a transient phenomena during ongoing CPAP therapy, persistence has been demonstrated in some patients. The CMS Medicare National Coverage Determination manual defines CompSA as a form of central apnea specifically identified by the persistence or emergence of central apneas or hypopneas (with a central apnea index of greater than 5) on exposure to CPAP or spontaneous-mode BPAP when obstructive events have disappeared.

\section{Results}

Literature search: The search strategy identified five retrospective case studies and one cross-sectional study that met the inclusion criteria to inform this topic (Table VII-1).

\section{Discussion}

Gilmartin et al (1) were the first to review CompSA, which was described as a distinct form of sleep apnea/hypopnea due to sleep state and respiratory control instability. Since then, the focus of several

\section{TABLE VII-1}

\section{Literature search results}

\begin{tabular}{|c|c|c|c|c|}
\hline \multirow[b]{3}{*}{ Author (reference), year } & \multirow[b]{3}{*}{ Study type } & \multirow[b]{3}{*}{ Patients, $\mathbf{n}$} & \multicolumn{2}{|r|}{ Outcome } \\
\hline & & & \multicolumn{2}{|c|}{ Prevalence of complex sleep apnea } \\
\hline & & & Initial & Late \\
\hline Morgenthaler et al (2), 2006 & Retrospective case series & 223 & $15 \%$ & - \\
\hline Lehman et al (3), 2007 & Retrospective case series & 99 & $13 \%$ & - \\
\hline Yaegashi et al (4), 2009 & Retrospective case series & 297 & $5.7 \%$ & - \\
\hline Javaheri et al (5), 2009 & Retrospective case series & 1284 & $6.5 \%$ & $1.5 \%$ \\
\hline Kuzniar et al (8), 2008 & Retrospective case series & $\begin{array}{l}13 \text { complex sleep } \\
\text { apnea/hypopnea }\end{array}$ & - & $\begin{array}{c}6 \text { of } 13(46 \%) \text { still had complex sleep apnea } \\
\text { after mean of } 195 \text { days of CPAP }\end{array}$ \\
\hline Dernaika et al (9), 2007 & Cross-sectional & $\begin{array}{l}21 \text { complex sleep apnea/ } \\
\text { hypopnea; } 21 \text { without }\end{array}$ & - & $\begin{array}{l}2 \text { of } 14 \text { (who have PSG) still have complex } \\
\text { sleep apnea after } 2 \text { to } 3 \text { months of CPAP }\end{array}$ \\
\hline
\end{tabular}


retrospective reviews (2-5) has been on describing the prevalence and demographic characteristics of treatment (CPAP and spontaneous mode BPAP) emergent central sleep apnea/hypopnea. Suggesting the acceptance of CompSA as a disease is the definition proposed by The Centers for Medicare and Medicaid Services, Medicare National Coverage Determination Manual (USA), which defined CompSA “... as a form of central apnea specifically identified by the persistence or emergence of central apneas or hypopneas upon exposure to CPAP or an E0470 device (spont mode BiPAP) when obstructive events have disappeared" (6). However, there is no universal agreement that CompSA is a distinct disease entity, evidenced by a recently published pro-con debate in the Journal of Clinical Sleep Medicine (6,7). Malhotra et al (7) argued that what has been described has a myriad of causes that require a myriad of treatments. Moreover, there is some suggestion that at least some CompSA is transient, although three flawed studies examining followup PSG after several weeks of CPAP therapy $(5,8,9)$ reported substantial variance in the decrease in CompSA. Gay (6) suggested that CompSA meets all the criteria necessary for a unique disease, with recognizable characteristics, plausible mechanisms and treatment response.

\section{Conclusions}

The literature is lacking in conclusive evidence that CompSA is a real syndrome. However, an emerging body of evidence does recognize treatment emergent central apnea as an entity that requires attention, with further research necessary.

\section{Question \#7}

Is CompSA a distinct clinical syndrome and, if so, what criteria should be used to make the diagnosis of CompSA?

\section{Recommendations}

The following recommendations are based on limited evidence and the consensus of the sleep apnea expert panel:

1. CompSA should be recognized as a distinct clinical entity. (Grade of recommendation: $2 \mathrm{C}$ )

2. CompSA is defined as a form of central sleep apnea specifically identified by the emergence of central apneas or hypopneas on exposure to CPAP or spontaneous mode BPAP when obstructive events have disappeared, with a central apnea-hypopnea index of $5 / \mathrm{h}$ or greater after CPAP has been titrated to eliminate OSAS. (Grade of recommendation: 2C)

\section{REFERENCES}

1. Gilmartin GS, Daly RW, Thomas RJ. Recognition and management of complex sleep disordered breathing. Curr Opin Pulm Med 2005;11:485-93.

2. Morgenthaler TI, Kagramanov V, Hanak V, Decker PA. Complex sleep apnea syndrome: Is it a unique clinical syndrome? Sleep 2006;29:1203-9.

3. Lehman S, Antic NA, Thompson C, Catcheside PG, Mercer J, McEvoy RD. Central sleep apnea on commencement of continuous positive airway pressure in patients with a primary diagnosis of obstructive sleep apnea-hypopnea. J Clin Sleep Med 2007;3:462-6.

4. Yaegashi H, Fujimoto K, Abe H, Orii K, Eda S, Kubo K. Characteristics of Japanese patients with complex sleep apnea syndrome: A retrospective comparison with obstructive sleep apnea syndrome. Intern Med 2009;48:427-32.

5. Javaheri S, Smith J, Chung E. The prevalence and natural history of complex sleep apnea. J Clin Sleep Med 2009;5:205-11.

6. Gay PC. Complex sleep apnea: It really is a disease. J Clin Sleep Med 2008;4:403-5.

7. Malhotra A, Bertisch S, Wellman A. Complex sleep apnea: It isn't really a disease. J Clin Sleep Med 2008;4:406-8.

8. Kuzniar TJ, Pusalavidyasagar S, Gay PC, Morgenthaler TI. Natural course of complex sleep apnea - a retrospective study. Sleep Breath 2008;12:135-9.

9. Dernaika T, Tawk M, Nazir S, Younis W, Kinasewitz GT. The significance and outcome of continuous positive airway pressure-related central sleep apnea during split-night sleep studies. Chest 2007;132:81-7.

\section{SECTION VIII: OPTIMUM PAP TECHNOLOGIES} Question

What are the optimum PAP technologies available to patients with OSAS?

\section{Introduction}

Although CPAP is typically the treatment of choice for individuals with OSAS, there is a proportion of patients for whom CPAP is not appropriate. Patients often complain of dyspnea or discomfort with CPAP, especially during expiration, which could lead to less than optimum usage. Alternatives to CPAP include variable expiratory pressure devices such as C-Flex (Philips Respironics, USA), BPAP (also known as variable PAP), or ASV.

Target populations include individuals with OSAS, those with OSAS who are intolerant of CPAP, those with mixed sleep apnea, those with CompSA or treatment emergent sleep apnea. Treatment for sleep hypoventilation syndromes and central sleep apnea are covered in other sections of the present clinical practice guideline. Originally, the CTS Guideline Statement on advanced PAP therapy did not cover this aspect of therapy. With the growing use of CPAP, the determination of which patients should be treated with CPAP therapy and which should be treated with other forms of PAP becomes of greater therapeutic importance.

\section{Results}

Literature search: A total of 733 citations were identified in the literature search. Of the 733 abstracts, nine RCTs (1-9), one prospective study $(10)$ and two clinical practice guidelines $(11,12)$ were identified to inform the discussion on the optimum role of advanced PAP therapies. In one RCT that was reported in German, sufficient data were reported in the English abstract to warrant inclusion in the body of evidence. Studies that only evaluated patients with central sleep apnea or chronic hypercapnic respiratory failure were excluded.

Study characteristics: Of the RCTs identified in the literature search, comparisons included CPAP versus BPAP $(1,9)$, C-Flex (2-4), pressure-relief CPAP (PRCPAP) (6), auto-adjusting CPAP based on the forced oscillation technique (APAPFOT) (7), proportional PAP (PPAP) (8) as well as one trial that compared noninvasive positive pressure ventilation (NPPV) versus ASV (5).

To be eligible for inclusion in the RCTs, patients were required to have OSA. Specific patient groups included individuals with stable systolic dysfunction (1), severe OSAS (2) or those with difficult to treat OSAS (7). One study (5) reported a population with mixed apneas in which six patients had CSAS or CSR, six had mixed apneas and nine had CompSA.

Outcomes of interest and associated measures included the AHI $(1,3,6,7)$, adherence $(1,2,4,9)$, patient satisfaction $(3,6-9)$, arousals $(4,5,6,7)$, inspiratory pressure $(1,7,8,9)$, subjective sleepiness using the ESS $(2,4)$, slow wave sleep $(4,8)$, respiratory events $(1,4)$, sleep latency (3), central apnea index (6), objective wakefulness using the modified maintenance of wakefulness test (2), simple reaction times assessed by the psychomotor vigilance task (2), total sleep time (8) and/or rapid eye movement (REM) (8).

In the nonrandomized comparison reported by Aloia et al (10), 89 patients with OSAS received either CPAP or C-Flex. Outcomes of interest included adherence over a three-month period, self-efficacy and subjective measures of sleepiness.

Study quality: As shown in Table VIII-1, the RCTs were small, with the majority of studies randomizing fewer than 20 patients per treatment arm $(1-5,7,8)$. Most of the trials used a crossover design (3-8), which allows for smaller sample sizes in which patients act as their own controls. In one study (6), a randomized, crossover design was used in the sleep laboratory, and a simple randomization was used in the home setting. Baseline characteristics appeared to be well balanced in two RCTs $(1,2)$ and one non-RCT $(10)$; however, statistical comparisons were only provided in two studies $(5,10)$. In one crossover trial (5), there were significant differences in several measures among 
TABLE VIII-1

Literature search results

\begin{tabular}{|c|c|c|c|c|c|c|c|}
\hline \multirow[b]{2}{*}{ Author (reference), year } & \multirow[b]{2}{*}{ Patients, n } & \multirow[b]{2}{*}{$\begin{array}{l}\text { Treatment } \\
\text { groups }\end{array}$} & \multicolumn{5}{|c|}{ Outcomes } \\
\hline & & & $\begin{array}{c}\text { Apnea hypopnea } \\
\text { index, events/h }\end{array}$ & $\begin{array}{c}\text { Adherence, } \\
\text { h/night }\end{array}$ & $\begin{array}{c}\text { Pressure, } \\
\mathrm{cmH}_{2} \mathrm{O}\end{array}$ & $\begin{array}{c}\text { Patient } \\
\text { satisfaction }\end{array}$ & ESS/QoL \\
\hline \multicolumn{8}{|l|}{ Randomized controlled trials } \\
\hline \multirow[t]{2}{*}{ Khayat et al (1), 2008} & 11 & CPAP & 4.0 & 3.6 & $8.4 \pm 2$ & NR & -4.7 \\
\hline & 13 & Bilevel & 1.4 & 4.5 & $\begin{array}{c}11.0 \pm 3 \\
(P=0.04)\end{array}$ & NR & -2.6 \\
\hline \multirow[t]{2}{*}{ Marshall et al (2), 2008} & 10 & CPAP & NR & $3.0 \pm 2.1$ & NR & NR & $8.1 \pm 4.9$ \\
\hline & 9 & C-Flex* & NR & $4.7 \pm 2.9$ & NR & NR & $\begin{array}{c}2.1 \pm 4.0 \\
(P=0.014)\end{array}$ \\
\hline \multirow[t]{2}{*}{ Mulgrew et al (3), 2007} & $15^{\dagger}$ & CPAP & $4.2 \pm 2.0$ & NR & NR & $7.2^{\ddagger}$ & NR \\
\hline & & C-Flex & $2.4 \pm 0.7$ & NR & NR & $7.9^{\ddagger}$ & NR \\
\hline \multirow[t]{2}{*}{ Wenzel et al (4), 2007} & $20^{\dagger}$ & CPAP & $8.9 \pm 3.3$ & $5.8 \pm 0.98$ & NR & NR & $7.5 \pm 3.7$ \\
\hline & & C-Flex & $7.5 \pm 5.1$ & $6.0 \pm 0.67$ & NR & 18 patients & $7.4 \pm 3.8$ \\
\hline \multirow[t]{2}{*}{ Morgenthaler et al (5), 2007} & $21^{\dagger}$ & NPPV & $6.2 \pm 7.6$ & NR & NR & NR & NR \\
\hline & & ASV & $\begin{array}{c}0.8 \pm 2.4 \\
(P=0.01)\end{array}$ & NR & NR & NR & NR \\
\hline \multirow[t]{2}{*}{ Nilius et al (6), 2006} & $52^{\dagger}$ & CPAP & $7.0 \pm 6.1$ & 5.2 & $8.7 \pm 1.3$ & - & 6.1 \\
\hline & & PRCPAP & $5.8 \pm 3.9$ & 5.3 & $9.0 \pm 1.7$ & $\begin{array}{c}\text { 个PRCPAP§ } \\
(P<0.05)\end{array}$ & 5.8 \\
\hline \multirow[t]{2}{*}{ Randerath et al (7), 2003} & $27^{\dagger}$ & APAPFOT & $13.8 \pm 13.2$ & NR & $5.8 \pm 3.9$ & 21 patients & $7.2 \pm 5.0$ \\
\hline & & Bilevel & $9.8 \pm 12.5$ & NR & $\begin{array}{l}8.3 \pm 2.5 \\
(P<0.01)\end{array}$ & $\begin{array}{l}6 \text { patients } \\
(P<0.05)\end{array}$ & $8.4 \pm 4.7$ \\
\hline \multirow[t]{2}{*}{ Juhász et al (8), 2001} & $12^{\dagger}$ & CPAP & NR & NR & $10.0 \pm 2.7$ & $2^{\Uparrow}$ & NR \\
\hline & & PPAP & NR & NR & $\begin{array}{c}8.5 \pm 2.4 \\
(P=0.002)\end{array}$ & $6 \pi$ & NR \\
\hline \multirow[t]{2}{*}{ Reeves-Hoché et al (9), 1995} & 36 & CPAP & NR & $5.0 \pm 0.19 * *$ & NR & NR & NR \\
\hline & 26 & Bilevel & NR & $4.9 \pm 0.23^{\star \star}$ & NR & NR & NR \\
\hline \multicolumn{8}{|l|}{ Prospective controlled studies } \\
\hline \multirow[t]{2}{*}{ Aloia (10), 2005} & 41 & CPAP & NR & 3.1 & NR & NR & $9.4 \pm 4.6$ \\
\hline & 48 & C-Flex & NR & $\begin{array}{c}4.8 \\
(P<0.01)\end{array}$ & NR & NR & $8.3 \pm 2.7$ \\
\hline
\end{tabular}

Clinical practice guidelines

$\begin{array}{ll}\text { SIGN } 73 \text { (11), } 2003 & \text { Management of obstructive sleep apnea/hypopnea syndrome in adults } \\ \text { AASM (12), } 2008 & \text { Clinical guidelines for the manual titration of positive airway pressure in patients with obstructive sleep apnea }\end{array}$

Data presented as mean \pm SD unless indicated otherwise. *Philips Respironics, USA; ${ }^{\dagger}$ Crossover randomized trial design; ${ }^{\ddagger}$ Visual analogue scores from 1 to 10 for which higher scores represent greater satisfaction; ${ }^{\S}$ The significant effect of less oral dryness with pressure-relief continuous positive airway pressure (PRCPAP) disappeared after a period of seven weeks; "The remaining patients expressed no preference; **The mean machine (timer hours \pm SEM) over a 12-month period. $\uparrow$ Increased; AASM American Academy of Sleep Medicine; APAPFOT Autoadjusting CPAP based on the forced oscillation technique; ASV Automatic servoventilation; Bilevel Bilevel positive airway pressure; ESS Epworth Sleepiness Scale; NPPV Noninvasive positive pressure ventilation; NR Not reported; PPAP Proportional PAP; QoL Quality of life; SIGN Scottish Intercollegiate Guidelines Network

the patient groups involved in the trial (CSAS, CSR and CompSA). In one study (9), $25 \%$ of patients were not evaluable, which led to a disproportionate number of patients in the CPAP group. Patients were assessed after one year (9), three months $(1,10)$, seven weeks (6), six weeks $(4,7)$, four weeks (2) or one night per treatment intervention $(3,8)$. One study reported a three-year follow-up of patients using C-Flex (4).

\section{Outcomes}

AHI: As shown in Table VIII-1, one study (5) reported a statistically significant difference in AHI between treatment interventions NPPV versus ASV. In that study, Morgenthaler et al reported a significant advantage in AHI with the use of ASV over that of NPPV $(0.8 \pm 2.4$ versus $6.2 \pm 7.6$, respectively; $\mathrm{P}=0.01)$. No other significant differences were detected between treatment groups in the remainder of the randomized studies $(1-4,6-9)$ or in the nonrandomized comparison (10).

Adherence: No significant differences were reported in adherence measures in any of the randomized comparisons that reported data on this outcome (1-9). Patients randomly assigned to C-Flex demonstrated greater adherence to treatment than those randomly assigned to CPAP (1.7 h) in one study (2), and patients randomly assigned to APAPFOT had greater adherence than those randomly assigned to BPAP therapy (7). However, given the small number of patients, conclusions regarding adherence according to treatment type are inconclusive. In one nonrandomized comparison (10), the mean treatment adherence was higher with C-Flex versus CPAP at two time points; weeks 2 to $4(4.2 \pm 2.4$ versus $3.1 \pm 2.8$; P not reported $)$ and weeks 9 to 12 (4.8 \pm 2.4 versus $3.1 \pm 2.8$; P not reported), respectively. Patient satisfaction/preference/subjective improvement: Overall, patient satisfaction with treatment was higher with C-Flex than with CPAP $(3,4)$, PRCPAP over CPAP (6) and with APAPFOT over BPAP (7), although the latter two trials $(6,7)$ only reported significant differences between treatment groups. In one trial of 15 patients (3), visual analogue scores showed no significant differences in patient satisfaction with C-Flex versus CPAP ( 7.9 versus 7.2; $\mathrm{P}=0.07$ ); however, 10 patients reported a preference for C-Flex while four patients preferred CPAP (total positive score of 68 , mean score of $4.8 \pm 4.3$ 
versus a total positive score of 13 , mean score of $0.9 \pm 1.9 ; \mathrm{P}<0.01$ ). In a second trial of C-Flex versus CPAP (4), 18 of 20 patients preferred C-Flex because of easier expiration. After a three-year follow-up period, 16 of 19 patients continued to use C-Flex on a regular basis. The trial by Nilius et al (6) reported no significant differences in patient complaints with PRCPAP versus CPAP, although initially, patients randomly assigned to PRCPAP experienced significantly less oral dryness.

ESS/QoL: In the randomized trial by Marshall et al (2), significant differences in improvement in subjective sleepiness (ie, ESS scores) were detected with CPAP versus C-Flex $(8.1 \pm 4.9$ points versus $2.1 \pm 4.0$ points; $\mathrm{P}=0.014$, effect size $=1.46$ ). This is in contrast to other findings in that study in which greater adherence was found with the use of C-Flex over CPAP. No other significant differences in ESS or QoL were reported in the remaining trials $(1,3-9)$ or in the nonrandomized comparison (10).

In one study (6), oral dryness was initially significantly lower with PRCPAP than with CPAP (1.4 versus 1.9; P<0.05); however, after seven weeks, that finding was no longer statistically significant.

Arousal indexes: In one trial (5), significant improvements in the respiratory arousal index were detected with ASV when compared with NPPV (6.4 \pm 8.2 versus $2.4 \pm 4.5 ; \mathrm{P}<0.01)$. In the trial by Nilius et al (6), no significant differences in the native arousal index were detected among treatment groups (35.2/h; 12.6/h CPAP and 12.9/h PRCPAP). Randerath et al (7) reported no significant differences in sleep quality in the comparison of BPAP versus APAPFOT (arousals: baseline 43/h $\pm 28.3 / \mathrm{h}, 17.7 / \mathrm{h} \pm 8.8 / \mathrm{h}$ versus $20.5 / \mathrm{h} \pm 10.7 / \mathrm{h}$ ).

Improvements in LVEF: In the study by Khayat et al (1), BPAP increased LVEF by $7.9 \%$ more than CPAP (95\% CI 2.3 to 13.4 ; $\mathrm{P}=0.01$ ). With BPAP, LVEF increased by $8.5 \%$ (95\% CI 3.7 to 13.4 ; $\mathrm{P}=0.002$ ), whereas with CPAP, there were no significant changes in LVEF $(0.5 \%$ [95\% CI -2.7 to $3.7 ; \mathrm{P}=0.7)$. The difference in LVEF improvement between the two groups was still significant after adjustment for adherence, level of treatment positive pressure, BMI and severity of OSAS

Inspiratory pressure: In two studies $(1,7)$, the average inspiratory pressure with BPAP was significantly higher when compared with CPAP (1) (10.9 versus 8.36; $\mathrm{P}=0.04)$ or with APAPFOT (7) $(5.1 \pm 1.7$ versus $8.3 \pm 2.5 ; \mathrm{P}<0.01)$. In one study (8), CPAP was associated with a significantly higher mean mask pressure than PPAP $(9.96 \pm 2.7$ versus $8.45 \pm 2.42 ; \mathrm{P}=0.002)$.

Sleep and wakefulness: No significant differences in objective wakefulness measured by the modified maintenance of wakefulness test were reported in one trial (1), nor were differences in simple reaction times using the psychomotor vigilance task (2).

In the nonrandomized study by Aloia et al (10), no significant differences in subjective sleepiness or in other functional outcomes were detected among treatment groups.

In the study by Juhász et al (8), total sleep time, slow wave sleep and REM sleep increased similarly with both CPAP and PPAP, while sleep stage non-REM 1 and 2 decreased. Another study (5) reported that no differences in total sleep time or sleep efficiency were detected between ASV and NPPV.

In one study (6), the central apnea index was $0.7 / \mathrm{h}$ with CPAP and $1.2 / \mathrm{h}$ with PRCPAP $(\mathrm{P}=0.04)$, and in a study of NPPV versus ASV (5) the central apnea index was $0.6 / \mathrm{h}$ with NPPV and $0.02 / \mathrm{h}$ with ASV $(\mathrm{P}<0.019)$.

Machine running time: In one study (9), no significant differences were seen between users of CPAP versus BPAP therapy in the percentage of time that the machines were running with the appropriate and prescribed pressure delivered $(80 \%$ versus $82 \%$; $\mathrm{P}$ not significant).

In one study (6), compliance after seven weeks was, on average, 9.4 min longer with PRCPAP than with CPAP but the difference was not significant.

Sleep latency: In one trial (3), no significant differences in sleep latency were detected between those treated with CPAP versus those treated with C-Flex $(12.3 \pm 3$ min versus $17 \pm 5 \mathrm{~min}, \mathrm{P}=0.4)$. None of the other trials $(1,2,4-9)$ reported data regarding this particular outcome.

\section{Clinical practice guidelines}

Using the Reeves-Hoché trial (9) as the evidence base, a clinical practice guideline by SIGN (11) recommended that BPAP ventilation should not be used routinely in OSAS, but should be reserved for patients with ventilatory failure. The rationale behind the recommendation is that although BPAP allows for independent adjustment of inspiratory and expiratory pressures rather than a fixed pressure as seen with CPAP, one RCT did not detect an advantage with BPAP, and BPAP may be more appropriate for patients with ventilatory failure.

The clinical practice guideline produced by the American Academy of Sleep Medicine (12) is essentially a consensus document that concluded that if patients are uncomfortable or intolerant of the high pressures associated with CPAP, an acceptable alternative is treatment with BPAP. The authors also concluded that if there are continued obstructive respiratory events at $15 \mathrm{cmH}_{2} \mathrm{O}$ of CPAP during the titration study, the patient could be switched to BPAP. The American Academy of Sleep Medicine also recommended that it is reasonable to consider ASV if patients experience CSR or CompSA during the titration study that is not eliminated by down titration of pressure. That recommendation was based on consensus and the limited evidence from one trial (5) in which ASV was shown to decrease respiratory events and improve objective sleep measures over NPPV in patients with CSAS/CSR, mixed sleep apnea and CompSA.

\section{Discussion}

Overall, there is little evidence to definitively inform the discussion on the most appropriate PAP technologies for individuals with OSAS. Important outcomes include the AHI, treatment adherence, patient satisfaction, ESS and QoL.

For AHI, ASV may be preferred over NPPV in patients with CSAS/CSR, mixed apneas and/or CompSA. No other meaningful differences in AHI were observed in the remainder of the identified literature.

While no significant differences were reported in adherence measures in any of the studies that reported data on that outcome, patient adherence was higher with C-Flex than with CPAP, and with APAPFOT than with BPAP therapy.

In terms of treatment satisfaction, patients expressed greater preference for C-Flex, PPAP and PRCPAP (at least initially) when compared with CPAP (8). In the comparison of APAPFOT versus BPAP therapy, most patients preferred APAPFOT.

Outcomes related to ESS or QoL were not consistently reported; however in one trial (2), significant improvements in ESS were detected with CPAP versus C-Flex; however these findings were in contrast to the adherence outcomes in the trial in which C-Flex was associated with greater adherence to treatment.

In the overall comparison of PAP interventions, there is surprisingly little evidence supporting the superiority of BPAP over CPAP. The largest trial (9) failed to demonstrate an improvement in symptoms or adherence with BPAP, while in a smaller study of 24 patients, BPAP was superior to CPAP in improving LVEF in patients with systolic dysfunction and OSAS. Larger trials would be needed to confirm the results and evaluate the mechanism behind that effect. It appears that PRCPAP and CPAP are comparable treatment options. Although patients who received PRCPAP experienced less mouth dryness during the first night of treatment, that difference disappeared over a period of seven weeks. In patients with difficultto-treat OSAS, APAPFOT appears to be as effective as BPAP therapy, but with the advantage of greater acceptance. Both NPPV and ASV were effective in normalizing breathing and sleep parameters; however, ASV appeared to be the more effective intervention. Unfortunately, there are no RCTs evaluating ASV versus other PAP technologies in the setting of OSAS or CompSA. 


\section{Conclusions}

Variable expiratory pressure technologies do not appear to have clear advantages over fixed CPAP in terms of adherence or clinical outcomes, but may be an option in CPAP-intolerant patients. BPAP should be reserved for patients with ventilatory failure. ASV may suppress sleep disordered breathing in patients with CompSA; however, whether this offers any long-term benefits over CPAP or BPAP in terms of adherence or quality of life is unknown.

Further areas of research include investigating whether BPAP offers any advantages over other lower cost treatment options in CPAP-intolerant patients with OSAS. RCTs comparing ASV with CPAP or BPAP using clinically important outcomes such as QoL, cardiovascular morbidity or treatment adherence would be beneficial. In addition, identifying OSAS populations that may benefit preferentially from BPAP is also a priority question of interest. In each case, well-designed RCTs evaluating clinically relevant outcomes in these populations are urgently needed.

\section{Question \#8 \\ What are the optimum PAP technologies available to patients with OSAS?}

\section{Recommendations}

The following recommendations are based on limited evidence from nine small RCTs, one prospective study, two clinical practice guidelines and consensus of the sleep apnea expert panel:

1. Variable expiratory pressure does not appear to have clear advantages over fixed CPAP with respect to adherence or clinical outcomes; however, it is recommended that it be considered an option in CPAP-intolerant patients. (Grade of recommendation: 2C)

2. BPAP should be reserved for patients with ventilatory failure. (Grade of recommendation: 2B)

3. ASV should be considered in patients with CSR syndrome or CompSA; however, the long-term benefits over CPAP or BPAP related to adherence or quality of life are unknown. (Grade of recommendation: $2 \mathrm{C}$ )

\section{REFERENCES}

1. Khayat RN, Abraham WT, Patt B, Roy M, Hua K, Jarjoura D. Cardiac effects of continuous and bilevel positive airway pressure for patients with heart failure and obstructive sleep apnea: A pilot study. Chest 2008;134:1162-8.

2. Marshall NS, Neill AM, Campbell AJ. Randomised trial of compliance with flexible (C-Flex) and standard continuous positive airway pressure for severe obstructive sleep apnea. Sleep Breath 2008;12:393-6.

3. Mulgrew AT, Cheema R, Fleetham J, Ryan CF, Ayas NT. Efficacy and patient satisfaction with autoadjusting CPAP with variable expiratory pressure vs standard CPAP: A two-night randomized crossover trial. Sleep Breath 2007;11:31-7.

4. Wenzel M, Kerl J, Dellweg D, Barchfeld T, Wenzel G, Köhler D. [Expiratory pressure reduction (C-Flex method) versus fix CPAP in the therapy for obstructive sleep apnoea.] Pneumologie 2007;61:692-5.

5. Morgenthaler TI, Gay PC, Gordon N, Brown LK. Adaptive servoventilation versus noninvasive positive pressure ventilation for central, mixed, and complex sleep apnea syndromes. Sleep 2007;30:468-75.

6. Nilius G, Happel A, Domanski U, Ruhle KH. Pressure-relief continuous positive airway pressure vs constant continuous positive airway pressure: A comparison of efficacy and compliance. Chest 2006;130:1018-24.

7. Randerath WJ, Galetke W, Ruhle KH. Auto-adjusting CPAP based on impedance versus bilevel pressure in difficult-to-treat sleep apnea syndrome: A prospective randomized crossover study. Med Sci Monit 2003;9:CR353-8.

8. Juhász J, Becker H, Cassel W, Rostig S, Peter JH. Proportional positive airway pressure: A new concept to treat obstructive sleep apnoea. Eur Respir J 2001;17:467-73.

9. Reeves-Hoché MK, Hudgel DW, Meck R, Witteman R, Ross A, Zwillich CW. Continuous versus bilevel positive airway pressure for obstructive sleep apnea. Am J Respir Crit Care Med 1995;151(2 Pt 1):443-9.

10. Aloia MS, Stanchina M, Arnedt JT, Malhotra A, Millman RP. Treatment adherence and outcomes in flexible vs standard continuous positive airway pressure therapy. Chest 2005;127:2085-93.

11. Scottish Intercollegiate Guideline Network (SIGN). 73: Management of obstructive sleep apnoea/hypopnoea syndrome in adults. A National Clinical Guideline. Edinburgh: SIGN, 2003.

12. Kushida CA, Chediak A, Berry RB, et al. Clinical guidelines for the manual titration of positive airway pressure in patients with obstructive sleep apnea. J Clin Sleep Med 2008;4:157-71.

ACKNOWLEDGEMENTS: The authors thank the CTS Respiratory Guidelines Committee for their expert guidance, and the CTS Guidelines Coordinators - Stella Muthuri and Candice Brown - for their support.

CONFLICTS OF INTEREST: Members of the Sleep Disordered Breathing Committee declared potential conlficts of interest at the time of appointment and these were updated throughout the process in accordance with CTS Conflict of Interest Disclosure Policy.

EDITORIAL INDEPENDENCE: The Canadian Thoracic Society receives unrestricted grants, which are combined into a central operating account to facilitate knowledge translation activities of all CTS Guideline Committees. Sources include the Canadian Institutes of Health Research, AstraZeneca Canada, Boehringer Ingelheim Canada, GlaxoSmithKline Inc, Pfizer and Talecris. 


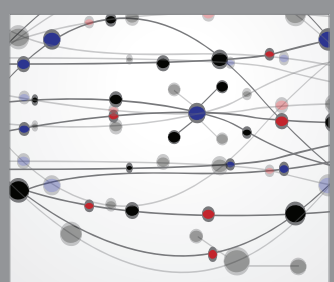

The Scientific World Journal
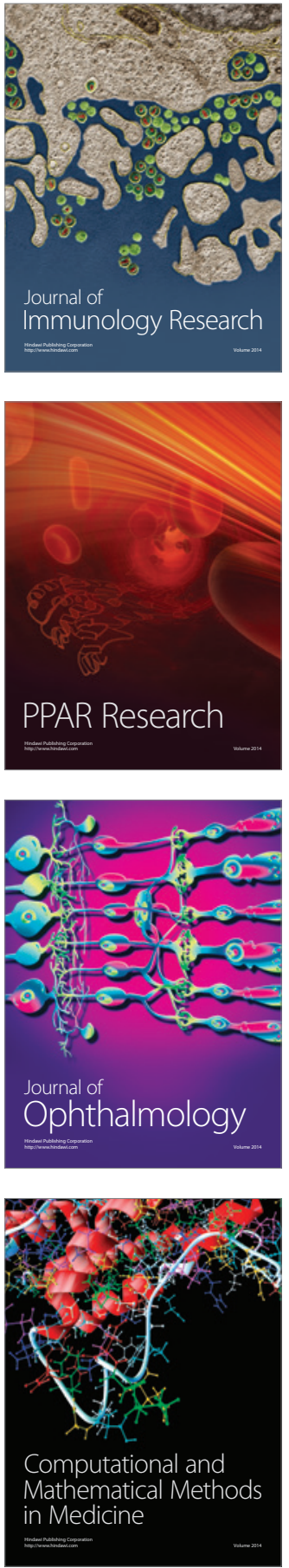

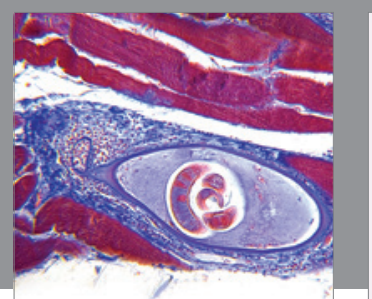

Gastroenterology Research and Practice

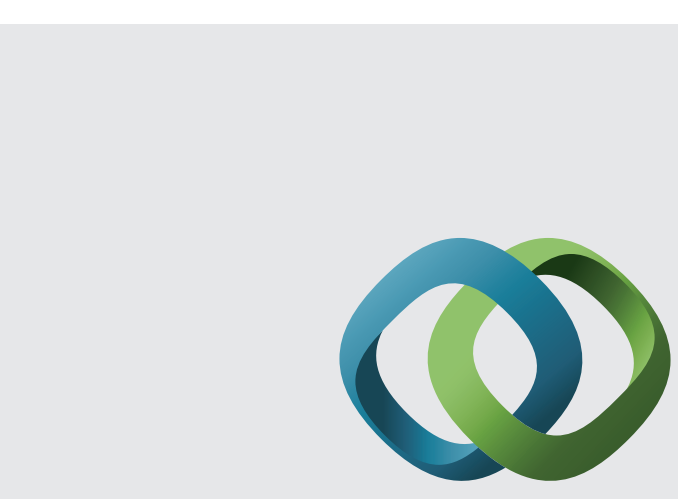

\section{Hindawi}

Submit your manuscripts at

http://www.hindawi.com
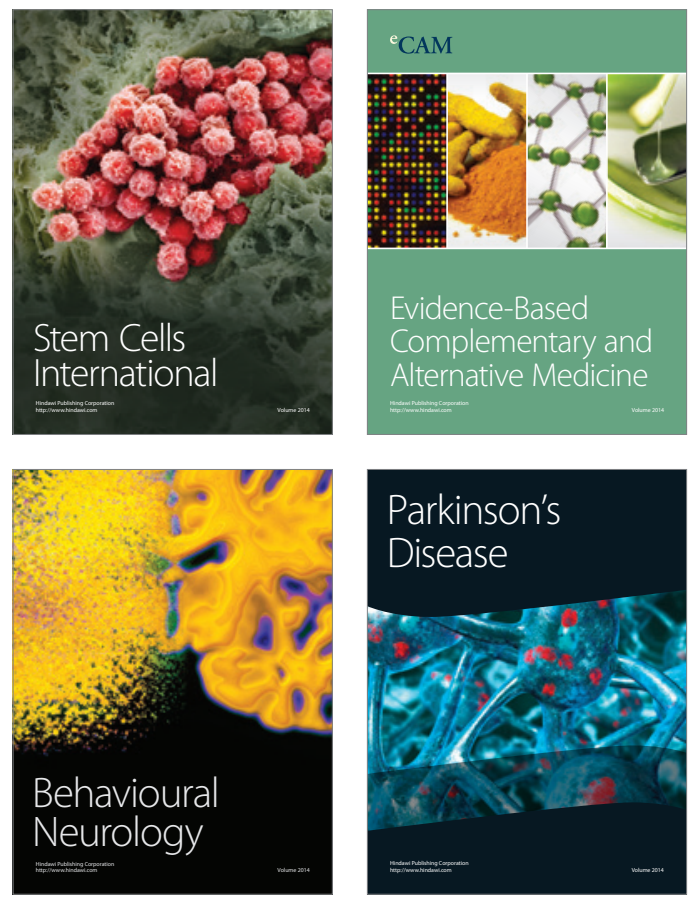
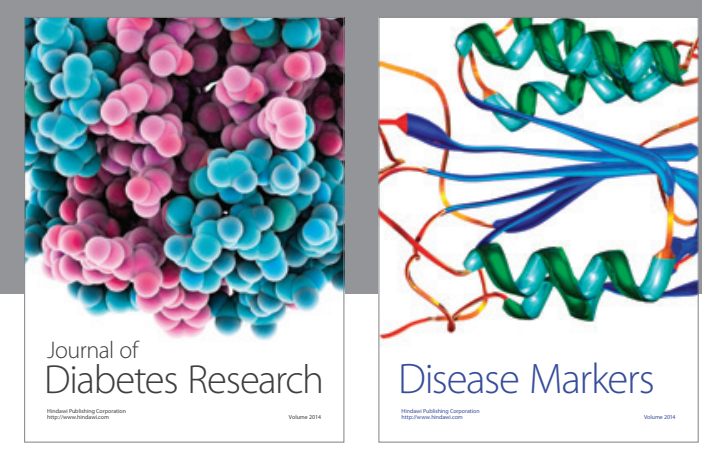

Disease Markers
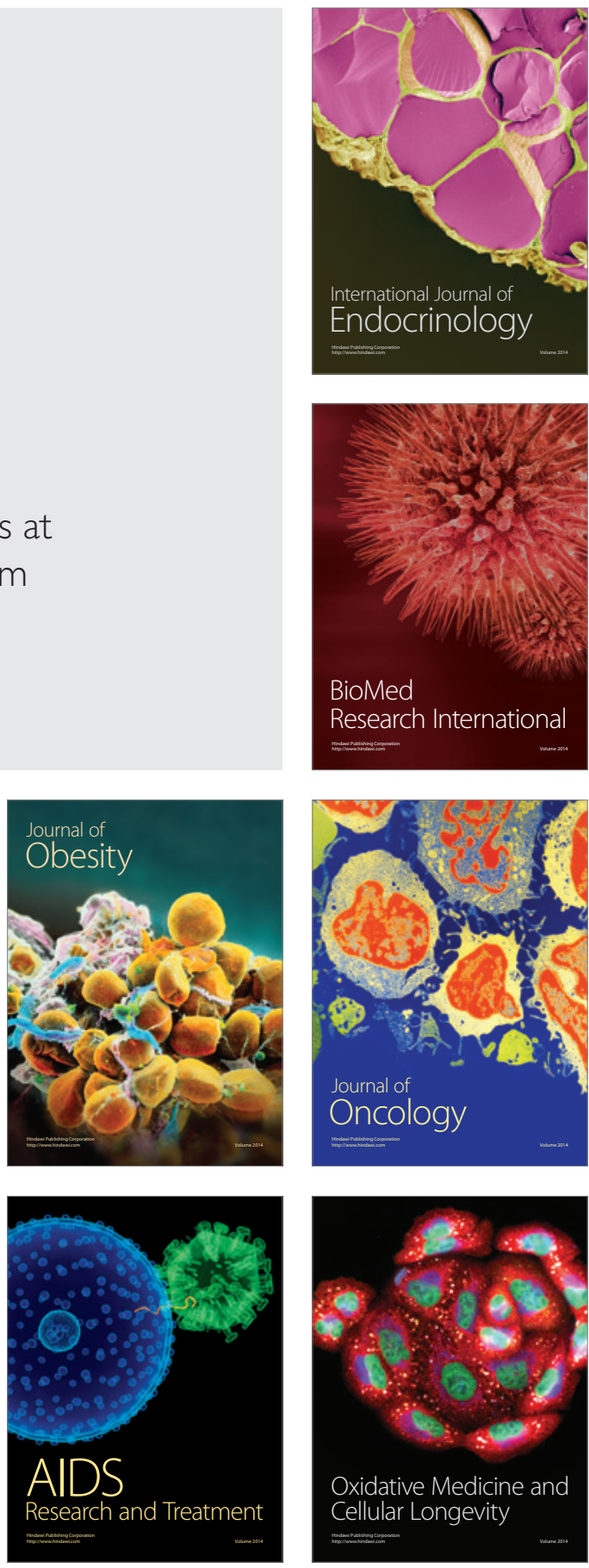